\title{
Adventive eriophyoid mites: a global review of their impact, pathways, prevention and challenges
}

\author{
Denise Navia $\cdot$ Ronald Ochoa $\cdot$ Cal Welbourn $\cdot$ Francisco Ferragut
}

Received: 15 April 2009/Accepted: 1 October 2009/Published online: 21 October 2009

(C) Springer Science+Business Media B.V. 2009

\begin{abstract}
Eriophyoids have high potential as adventive mite species (AMS) because their small size make them difficult to detect, and can be easily distributed in world trade. Economic, social and environmental impact from adventive eriophyoid mites has been significant. Considerable attention has been given to adventive insect species while adventive mites have received little attention and little information is available for eriophyoids. This paper summarizes information on adventive eriophyoid mites, their impact, and the history of some important invasions. The status of adventive species of eriophyoids introduced as biological control agents of weeds is presented. A list of eriophyoid mites reported as invasive species worldwide is given. Pathways of concern and biosecurity actions to reduce the risk of eriophyoid mites are discussed. The need to raise public awareness of the risk and importance of these tiny organisms as AMS is emphasized. Scientific and technical challenges to deal with adventive eriophyoids are discussed.
\end{abstract}

Keywords Acari - Eriophyoidea - Invasive alien species · Pathways · Quarantine · Biosecurity

\footnotetext{
D. Navia (ه)

Laboratório de Quarentena Vegetal, Embrapa Recursos Genéticos e Biotecnologia, CP 02372, Brasília, DF 70.770-900, Brasil

e-mail: navia@cenargen.embrapa.br

R. Ochoa

Systematic Entomology Laboratory, Agriculture Research Service,

United States Department of Agriculture, BARC-West, Beltsville, MD 20705, USA

e-mail: Ron.Ochoa@ars.usda.gov

C. Welbourn

Division of Plant Industry, Florida Department Agriculture \& Consumer Services,

P.O. Box 147100, Gainesville, FL 32614-7100, USA

e-mail: welbouc@doacs.state.fl.us

F. Ferragut

Instituto Agroforestal Mediterráneo, Universidad Politécnica de Valencia,

Camino de Vera, s/n, 46022 Valencia, Spain

e-mail: fjferrag@eaf.upv.es
} 


\section{Introduction}

The term "adventive species" refers to alien or exotic species, subspecies, biotypes, races or strains introduced into an area outside its native range and includes many species that cause ecological or economic problems throughout the world (Wheeler and Hoebeke 2009). Adventive species, also called "Invasive Alien Species" (CBD 2002), are considered to be a direct driver of biodiversity loss across the globe and are causing enormous damage to valuable agricultural systems (McNeely et al. 2001). These species can act as vectors for new diseases, alter ecosystem processes, change biodiversity, disrupt cultural landscapes, reduce land and water value for human activities and cause other socioeconomic consequences (DAISIE 2009). Bioinvasion is one of the great economic and ecological issues of our time (McNeely et al. 2001). The cost of adventive species to national economies has been estimated at hundreds of billions of dollars annually (CBD 2002).

The globalization of travel and trade has facilitated introductions of adventive species since the Industrial Revolution in the nineteenth century. Many species introduced decades ago have only recently begun to spread rapidly in ecosystems. There has been an upward trend in the establishment of non-indigenous species and large numbers of invasive species have been documented (Randall and Marinelli 1996; Vitousek et al. 1997; Nico and Fuller 1999; Xie et al. 2000). An adventive species can be transported intentionally or unintentionally by man (di Castri 1990; Wheeler and Hoebeke 2009). Intentional transport is the movement of organisms to a new area for an express purpose, such as the importation of ornamental or crop plants, or as biological control agents. Unintentional transport refers to the movement of non-native species as a secondary result of the intentional transfer of another product. Exotic species can be transported on or within other species, such as on host plants, within cargo holds or in packing materials. The study of adventive species may provide opportunities to understand basic evolutionary processes, predict the risk of their spread in new regions and develop pest control and quarantine strategies.

Phytophagous mites are a group of organisms where adventive species can greatly impact agroecosystems and natural terrestrial ecosystems. Among the phytophagous mites, eriophyoid species have highest potential as adventive mite species (AMS). There are several examples of inadvertent introductions of eriophyoid mites in new areas where they found appropriate conditions to develop in the absence of efficient natural enemies, resulting in accentuated damage to the infested crops and consequent serious social-economic problems.

This paper discusses the importance of eriophyoid mites as AMS, with a brief review of some AMS; their ecological and economic impact, a discussion on the pathways available to eriophyoid mites and the preventive procedures for invasive alien eriophyoid mites. The research related to adventive eriophyoid mites to be addressed in the near future is discussed.

\section{Eriophyoids as adventive species}

Phytophagous mites are good candidates to become adventives species, because of the characteristics that make their potential to damage the host plants, vector plant diseases, development of resistance to pesticides, difficulties to detect, capacity to survive adverse conditions, parthenogenetic reproduction, disperse by wind and adaptation to new host plants (Navia et al. 2007a). Most of the mentioned traits can be found among eriophyoid mites making them high potential as adventive species. 
Among the plant feeding mites, the Eriophyidae are the second most economically important family of pests after the Tetranychidae (Lindquist and Amrine 1996). Eriophyid species are known to cause considerable damage, assuming pest status in crops of socialeconomic importance. Eriophyoids can be serious pests of horticultural crops, like Aculops lycopersici (Tryon) a key pest of tomato and other Solanaceae worldwide (Perring 1996). In temperate and tropical fruit tree crops, Aculus schlechtendali (Nalepa) is a pest of apples in Europe (Easterbrook 1996; Gólya and Kozma 1998; Angeli et al. 2007) and Aceria guerreronis Keifer is an important pest of coconut palms, Cocos nucifera L., worldwide (Moore and Howard 1996; Fernando et al. 2002; Nair et al. 2005). In cereal crops, Aceria tosichella Keifer is a widespread pest of wheat and corn (Oldfield and Proeseler 1996; Harvey et al. 2002) and in forest and ornamental trees, Trisetacus juniperinus (Nalepa) is a pest of evergreen cypress in Europe and North America (Castagnoli 1996; Castagnoli et al. 2002; Simoni et al. 2004).

Mites are considered efficient vectors of plant diseases (viruses and virus-like). The transmission of 21 pathogens by 13 species of phytophagous mites to at least 34 plants has been reported in the literature (Oldfield and Proeseler 1996; Seifers et al. 1996, 1998; Chagas et al. 2001; Childers et al. 2001; Stephan et al. 2008). Most mite species that are known to vector plant pathogens are in the Eriophyidae. At least 26 plant diseases are associated with eriophyid mites (Jones 1999). As a result of their tiny size and very short stylets (ca $20 \mu \mathrm{m}$ ) feed only the epidermal cells of their plant hosts where they may acquire and transmit disease agents to these plant cells (Jones 1999). The location of these different viruses in epidermal cells of their plant host suggest that the mode of transmission by their mite vector should be of a non-persistent or semi-persistent type, but the data indicate that some may be of a persistent (circulative) type (Jones 1999). Eriophyoid mites can then disseminate phytovirus to non affected areas if they are transported after the virus acquisition period.

Resistance to pesticides accentuates the economic importance of the pests, due to increased difficulties in their control. Even if a species is already present in an area, new introductions should be avoided because they may include a resistant biotype. Resistance to pesticides has been reported in seven eriophyoid species: Aculops lycopersici on tomato and Aculops pelekassi (Keifer), Aculus cornutus (Banks), Aculus fockeui (Nalepa \& Trouessart), Aculus malivagrans (Keifer), A. schlechtendali and Phyllocoptruta oleivora (Ashmead; Michigan State University 2004) all on fruit trees.

Mites often are difficult to detect due to their small size and they are often hidden on the host plant. Eriophyoidea are among the smallest arthropods, measuring from 86 to $500 \mu \mathrm{m}$ in length, and often impossible to detect with the naked-eye or $10 \times$ hand lens. Eriophyoidea colonies can commonly develop in buds, sheaths and other protected areas of the plant (Lindquist et al. 1996). Usually symptoms of a mite infestation appear only at high populations. These characteristics make interception of eriophyoid mites associated with plants and plant products at points of entry or departure difficult.

When phytophagous mites are introduced into a new region they may spread in the environment, but if their preferred host is not available they either die or they may adapt to another host. This occurs more frequently in polyphagous species in the Tetranychoidea than in eriophyoids which are usually more host specific. The majority of eriophyoid species described to date are reported from a single host species, others are limited to species within a single genus or on a few species of closely related genera of the same plant family (Oldfield 1996). There are uncertainties regarding the identity of Eriophyidae reported to be host generalists. For example, molecular and host acceptance studies on Abacarus hystrix (Nalepa), an eriophyid reported to occur on at least 30 genera of grasses, 
supported the hypothesis that this species is a species complex and not a single species (Skoracka 2008).

However, evidence suggests that some invasive species are able to extend their host range. The coconut mite A. guerreronis probably originated in tropical America (Navia et al. 2005) and has spread to most of the coconut production areas of the world. Aceria guerreronis has been found infesting palmyra palm fruits, Borassus flabellifer L., in India (Ramaraju and Rabindra 2002) and Sri Lanka (de Moraes, personal communication). The palmyra palm is native to Southern and Southeast Asia and is widely cultivated in urban and rural areas. The observation of A. guerreronis on palmyra palm was made soon after A. guerronis was reported in Southeast Asia and the subsequent explosion in its populations, which supports the hypothesis that the mite expanded its host range in a period of adaptation to the new environment. Samples of mites attacking B. flabellifer plants in India and Sri Lanka should be tested to confirm that they represent the same taxon reported from coconut and not a cryptic species. The coconut mite has also moved to the queen palm Syagrus romanzoffiana (Cham.) Glassman seedlings in nurseries in California and Florida, USA (Ansaloni and Perring 2004; Welbourn unpublished data). This palm is native to South America and is widely cultivated as an ornamental in Florida and California. Nuclear and mitochondrial sequences of coconut mite population from S. romanzoffiana from California were identical or similar to that of other populations found on coconut in the Americas (Navia et al. 2005), indicating that it is a single species as opposed to one or more cryptic species. During surveys of eriophyoid mites on native palms (Arecaceae) in Brazil, $S$. romanzoffiana leaves and fruits were extensively sampled in search of new hosts of A. guerreronis, in natural areas presenting a high density of this palm. The coconut mite was not found during these surveys which indicate that queen palm is not a host for A. guerreronis in its areas of natural occurrence in Brazil (Navia 2004). However, evidences are provided in Navia et al. (2005) that the coconut mite does feed on queen palm seedlings in North America.

Another example of host expansion appears to be A. lycopersici that probably originally fed on wild solanaceous plants native to the Americas and its association with tomato is a recent event (Oldfield 1996). Although there is evidence supporting the hypothesis of host range expansion for certain species of eriophyoid mites in new areas, it remains a controversial subject, and there needs to be additional research on host acceptance (see Michalska et al. 2009; Navajas and Navia 2009).

Eriophyoid mites have a considerable capacity to survive adverse conditions. Many species are able to survive the harsh low temperatures of winter in the egg stage or through diapause. Survival of 50-76\% of A. schlechtendali deutogynes during the winter has been reported in Poland (Kozlowski and Boczek 1987). Eggs of Aceria tulipae Keifer can endure temperatures of $-31^{\circ} \mathrm{C}$ for $2.5 \mathrm{~min}$ (Jeppson et al. 1975). Generally, mites can survive lower temperatures than their host plants. This characteristic enables mites to survive when associated with plant products transported for extended periods of time at low temperatures, as, for example, fresh fruits, whose are usually transported at temperatures from 2 to $6^{\circ} \mathrm{C}$.

Lastly, it is not necessary for a large number of exotic eriophyoid mites to be introduced into a new habitat for its establishment. Arrhenotokous parthenogenesis (i.e. fertilized egg become female and unfertilized eggs become males) is common in most phytophagous mites including the eriophyoids. Arrhenotokous species are able to start a new population from a single female. While arrhenotoky has been reported in the Eriophyoidea, thelytokous parthenogenesis has not been found in this group (Helle and Wysoki 1996). 


\section{Adventive eriophyoid mites and their impact}

Most agricultural pests are represented by non-native species (Pimentel 2002). Pimentel estimated the annual costs associated with arthropods introduced into the United States to be about 20 billion dollars. Besides the economic losses, the ecological impact by adventive species occurs at different levels including their direct effect on individuals, populations or native communities and indirect effects on ecosystems, through more complex mechanisms and cascading effects (NRC 2002). Literature reviews of the ecological impact of invasive alien species have been published on insects (Kenis et al. 2009), but mites are rarely listed as adventive species because little is known about their ecological effects.

Table 1 summarizes a literature review of eriophyoid species reported as invasive in many geographical areas. The table includes available data on country, host plants and whether the introduction was accidental or deliberate (i.e. as biological control agents of weeds). Eriophyoid mites representing 85 species and 30 genera are mentioned as invasive; genera with the higher number of invasive species include Aceria (29), Eriophyes (7), Aculops (5), Aculus (4), Acalitus (3), Phyllocoptes (3) and Trisetacus (3). Most of host plants with invasive eriophyoids were fruit or ornamentals due to the extensive international movement of these plants and/or their products (i.e. fresh fruits, plants for planting, cuttings, and/or budwood).

\section{Adventive eriophyoid mites in Europe}

The "Delivering Alien Invasive Species in Europe" (DAISIE) was a 3 years project, funded by the European Union, to provide new knowledge on biological invasions in Europe. This project provided an inventory of more than 11,000 alien species in Europe (including harmful and harmless; DAISIE 2009; www.europe-aliens.org). This list includes thirteen eriophyoid species in the genera Aculops (4), Aceria (3) and one each in following genera: Acaphylla, Calacarus, Eriophyes, Phyllocoptes, Tegolophus and Trisetacus.

Some pest species of crops in Europe are also found in other regions of the world. Several are vagrant species infesting citrus in the Mediterranean region. The citrus bud mite, Aceria sheldoni (Ewing), occurs in all of the citrus-growing regions of the world where it lives under and within the buds of lemons causing structural modifications in leaves and fruits, to develop abnormally (Jeppson et al. 1975). The citrus rust mite, $P$. oleivora, was not included in the DAISIE list but it is already present in Sicily and Cyprus (de Lillo 2004). This eriophyid causes considerable injury to citrus, affecting the quality of fruits in most of the citrus-growing areas of the world, and is a key pest to citrus in Florida and Israel. Symptoms are very characteristic; the affected fruits show russetting and are small in diameter and weight. Similar effects of fruit damage have been observed in the pink citrus rust mite, A. pelekassi, another widespread eriophyid mite that also occurs in other European countries or localities, for example in Italy, Greece, Malta, Ukraine and Montenegro (de Lillo 2004).

The pear leaf blister mite, Eriophyes pyri (Pagenstecher), is distributed worldwide as an important pest of fruit trees (Easterbrook 1996). The mite causes blisters and galls on the underside of developing pear and apple leaves that turn from red to dark brown and black (Easterbrook 1996). Probably the pear leaf blister mite has been disseminated around the world, including Europe, through transport of pear propagation material (Jeppson et al. 1975).

The tomato russet mite $A$. lycopersici has a cosmopolitan distribution and is a serious pest of tomato plants and other solanaceous crops grown between $60^{\circ}$ north and $60^{\circ}$ south 


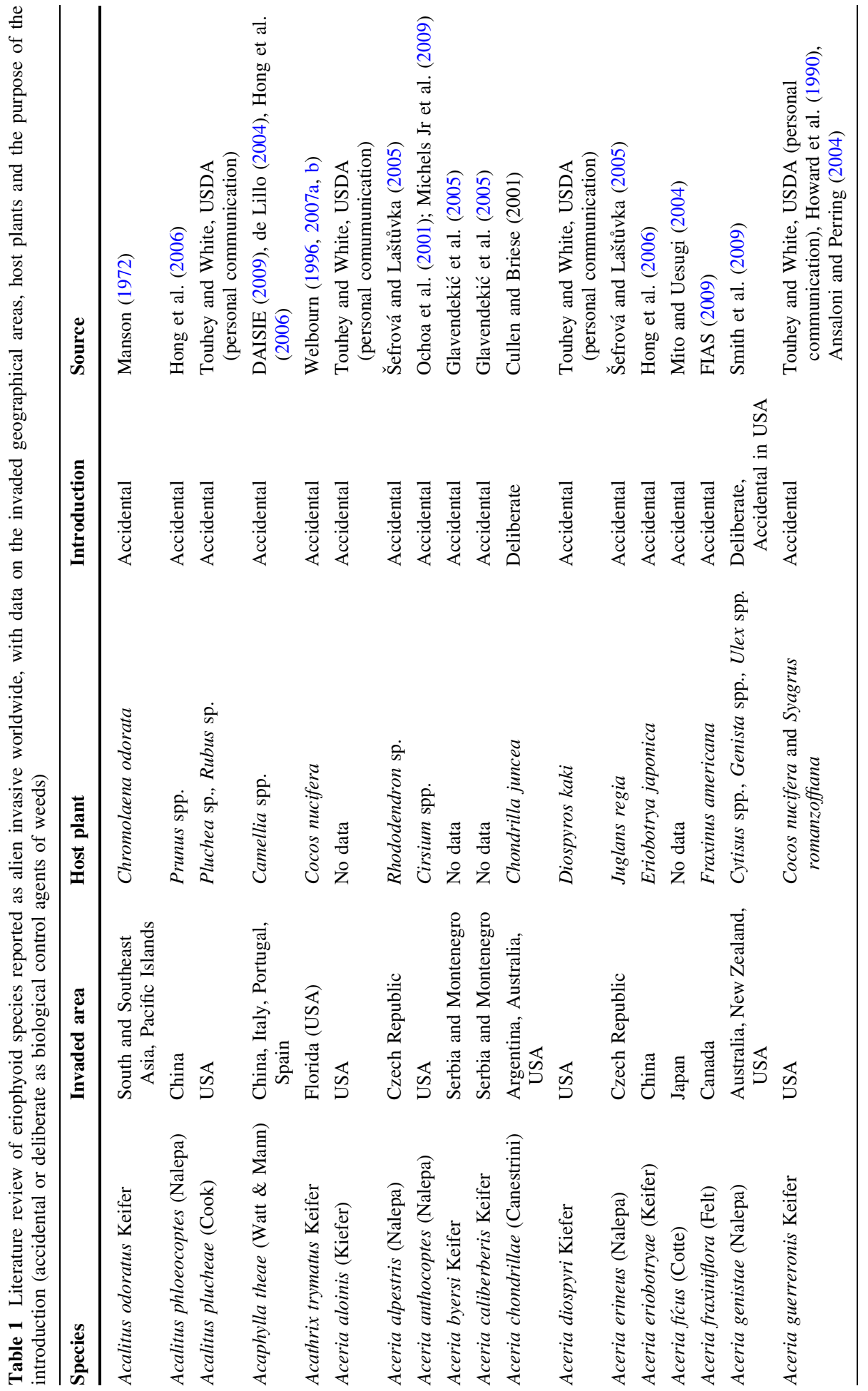




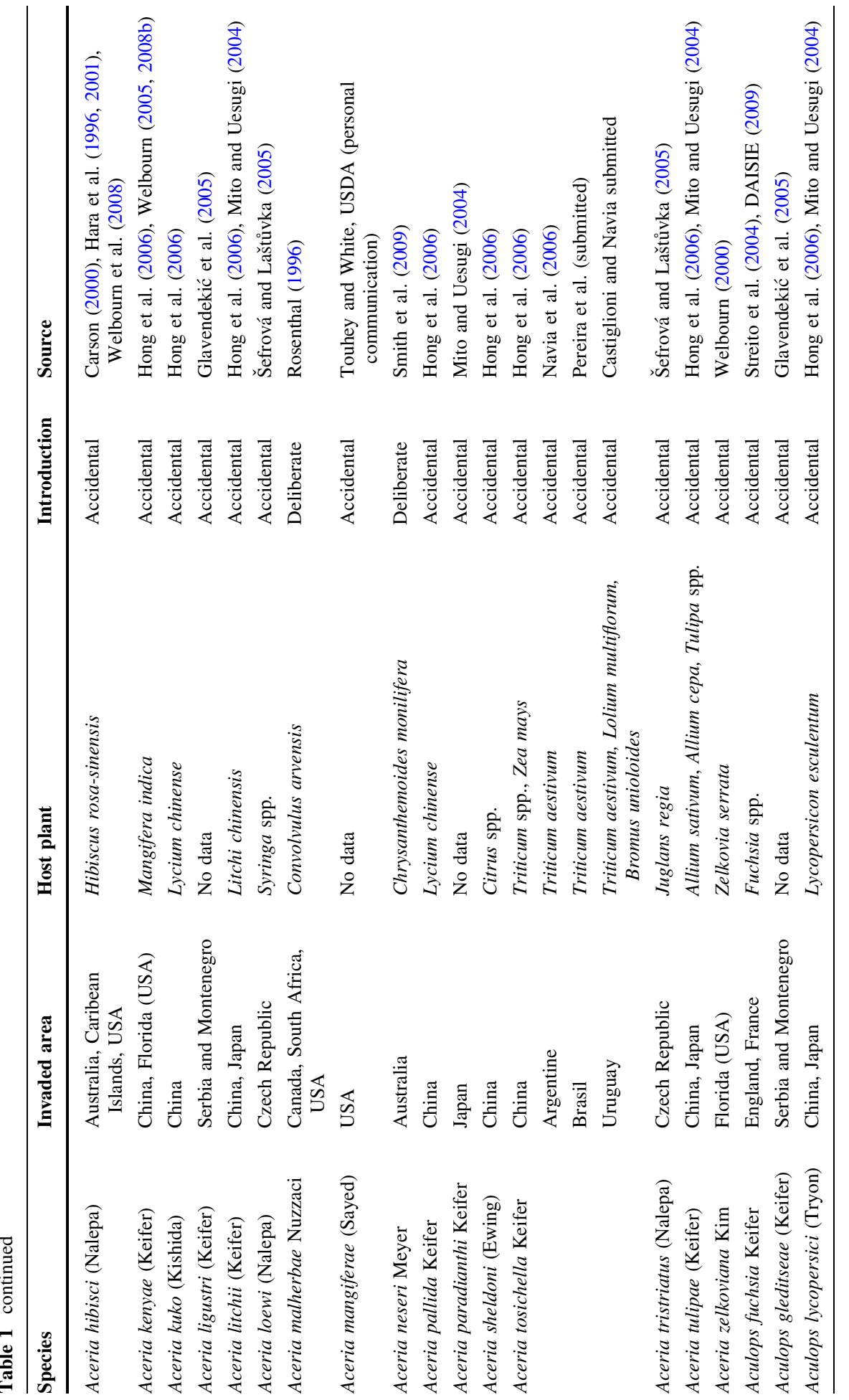




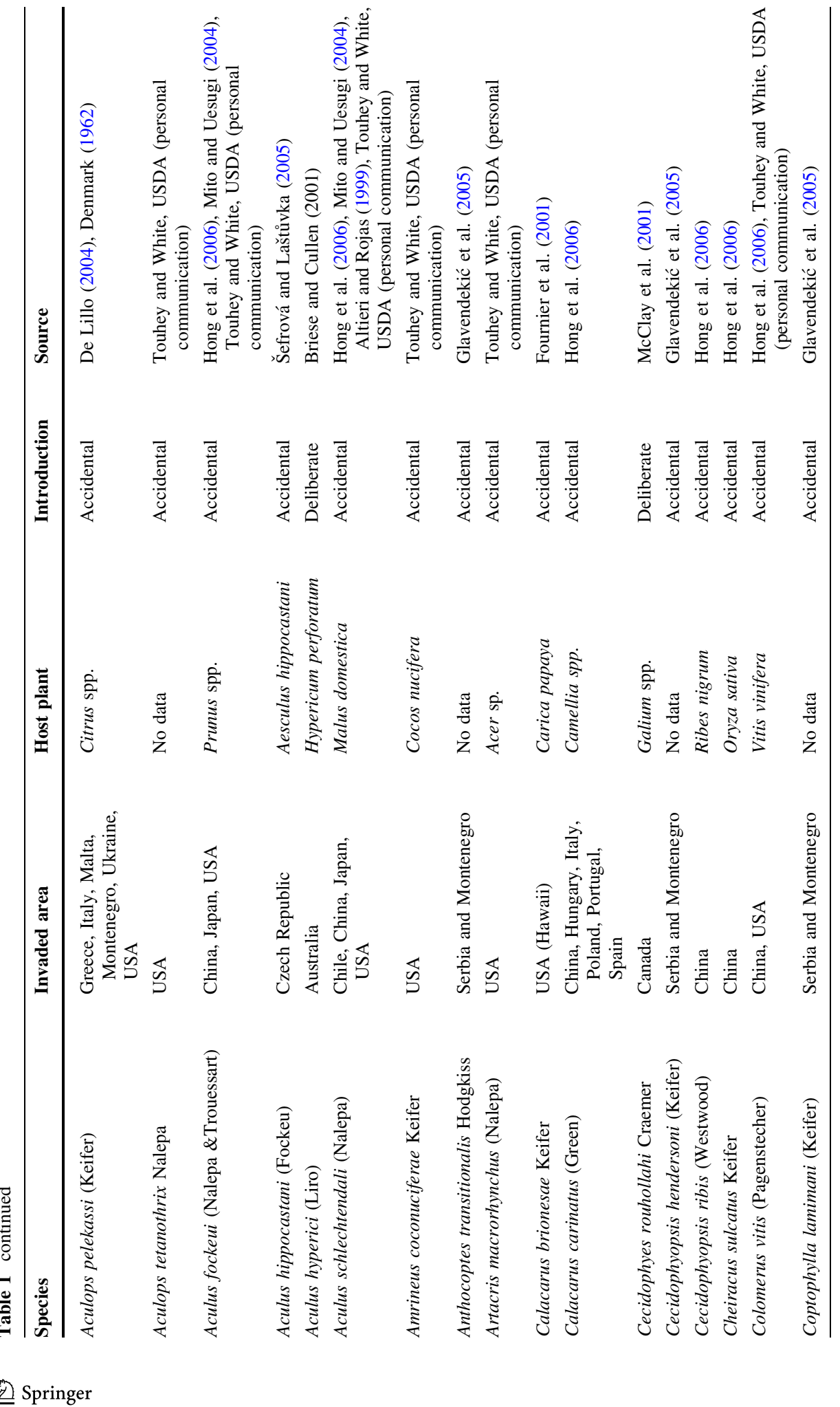




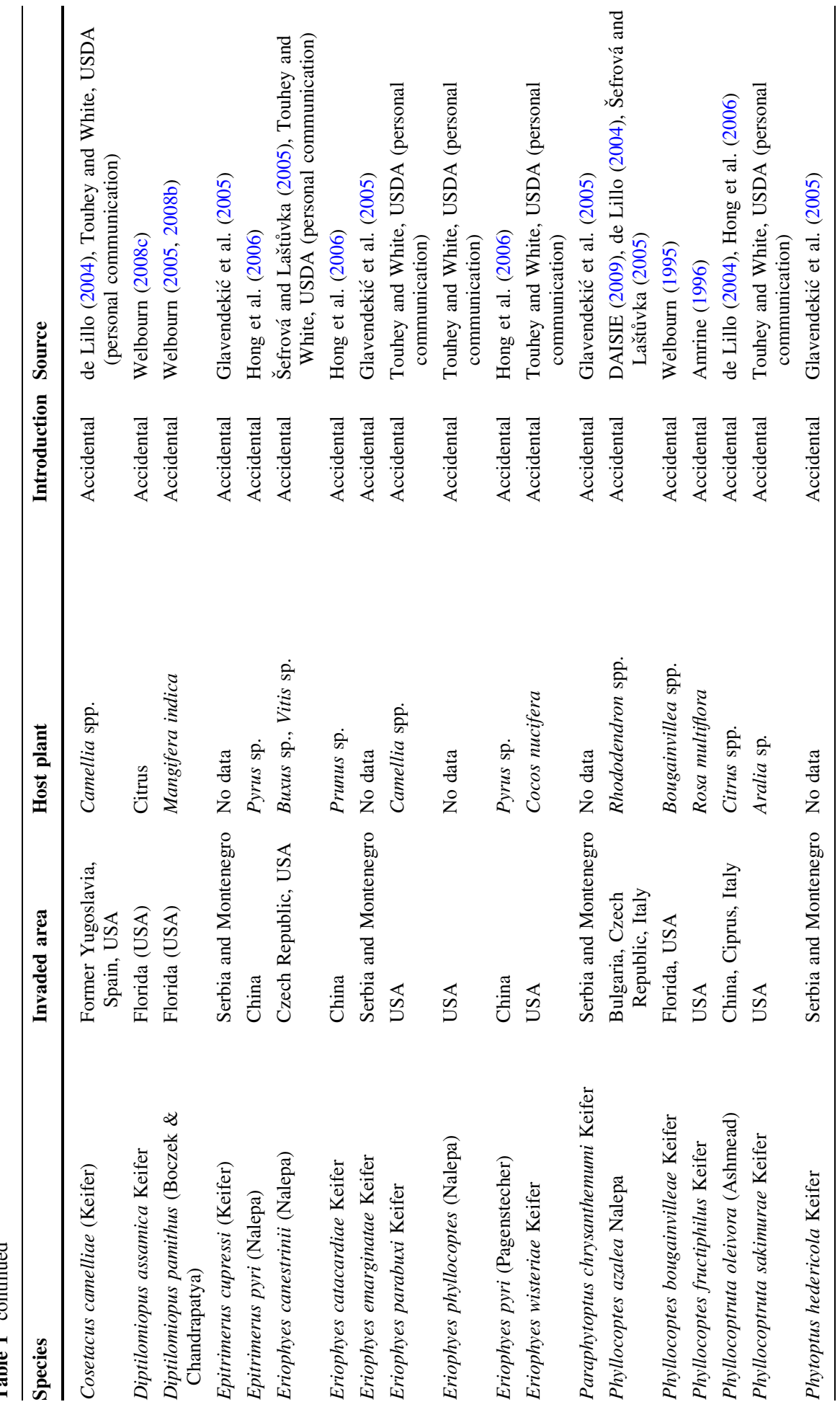




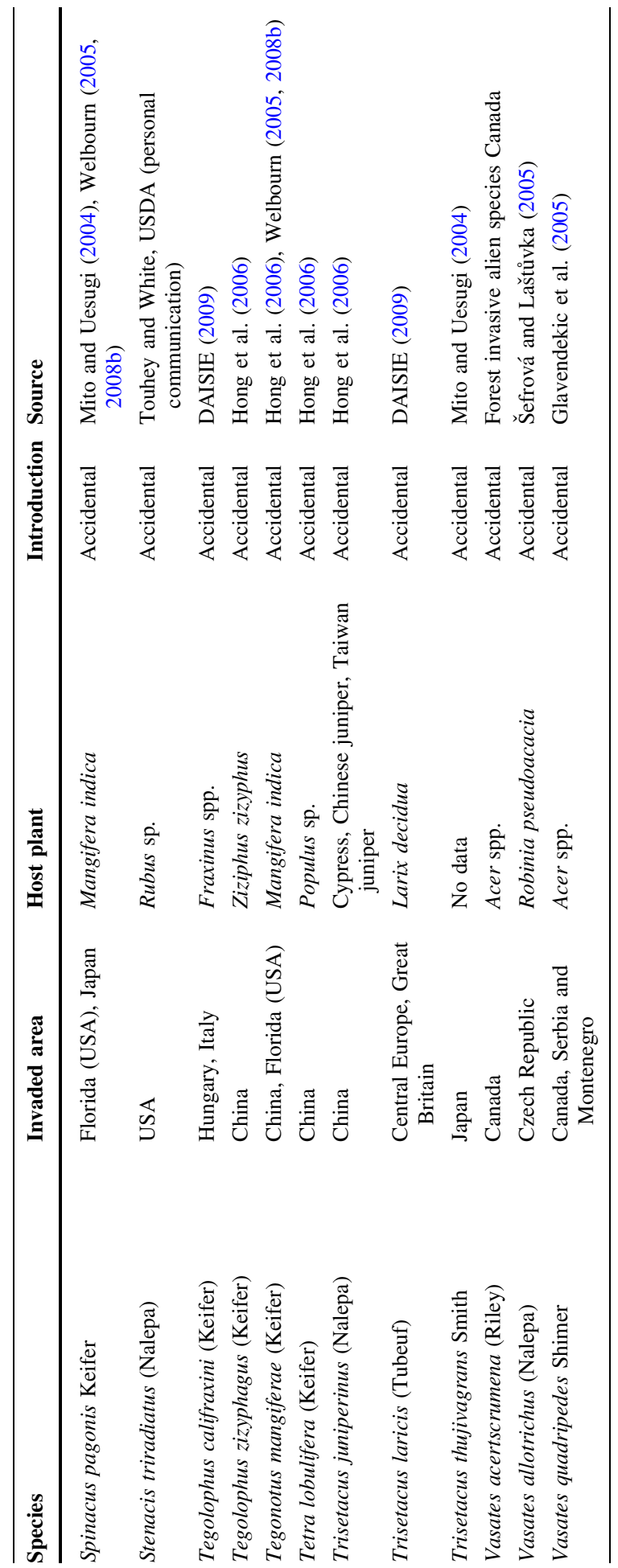


latitudes. Stems with high populations of the mite may affect fruit quality (Perring 1996). Mite feeding produces russetting which turn brown and paperlike but do not wilt down. This mite lives on leaves of many solanaceous plants, but particularly tomato and it usually kills its host (Jeppson et al. 1975). De Oliveria et al. (1982) reported crop reductions of $66.5-1.8 \%$ when plants were infested early or late in the season, respectively.

Aceria tristriatus (Nalepa) and A. erineus (Nalepa) are widespread in Europe and are the most common and injurious eriophyoids found on cultivated walnuts. The walnut blister mite, A. tristriatus, causes the formation of small pustules along midribs and lateral veins. Aceria erineus causes the formation of erineum patches covered with yellowish hairs on the underside of leaves among which the mites can be found. Convex swellings occur on the upper surface of the leaf above of these areas. Damage produced by these species causes a reduction in the leaf surface but does not normally affect yield (Castagnoli and Oldfield 1996).

Some invasive eriophyoid mites considered to be pests of ornamentals in Europe are crop pests in other regions of the world. An example of this is the pink tea rust mite, Acaphylla theae (Watt \& Mann), and the purple tea mite, Calacarus carinatus (Green), which are among the most important tea pests in Southern Asia. Both species have been recorded in Italy, Spain and Portugal, and C. carinatus has also been reported in Poland and Hungary. In northwest Spain (Galicia) and northern Portugal the mites were found on the leaves of Camellia trees in parks and public and private gardens where they were associated with Cosetacus camelliae (Keifer), an eriophyid mite commonly found on this host (Mansilla et al. 2003).

Other eriophyoid invasive mites reported in Europe as pests of ornamental crops are Aculops fuchsia Keifer, causing galls in fuchsia, and Phyllocoptes azaleae Nalepa, causing leaf rolling in Azalea indica L. The former is an important pest of fuchsias causing deformation of leaves and flowers. Galls become swollen and blistered and often reddened (Keifer et al. 1982, Koehler et al. 1985). The species was described from southern Brazil and is probably native to South America. It was later recorded in California in 1981, France in 2003 (Streito et al. 2004) and England in 2007. This species was included in the EPPO (European and Mediterranean Plant Protection Organization) Alert Lists because it may threaten fuchsias in the EPPO region.

Šefrová and Laštůvka (2005) published a catalogue of alien animal species in the Czech Republic with data on their origin, pathway of introduction, invasive status and feeding requirements. A total of 595 species were listed, including eight eriophyid mites. Among them Aculus hippocastani (Fockeui), a common species which causes erineas under the leaves of the Horse-chestnut, Aesculus hippocastanum L., widely cultivated as ornamental tree throughout many temperate countries. The erineas, placed on the angle of the veins of the leaflet, present trichomes that are white at first and turn brown later. Vasates allotrichus (Nalepa) produces leaf rolling on the Black locust, Robinia pseudoacacia L., a tree native to the United States and widely planted and naturalized elsewhere in temperate North America, Europe and Asia, where it has been considered an invasive species in some areas.

Glavendekić et al. (2005) reviewed the alien insects and mites in Serbia and Montenegro between 1979 and 2004 and twelve Eriophyidae and one Phytoptidae species were included, without host plant information. Some of them, like the privet mite Aceria ligustri (Keifer), are potential pests that can cause considerable damage in urban areas. The privet mite lives as vagrant on leaves and buds of Ligustrum (Oleaceae) hedges where it can cause curling, bronzing and rusting of infested leaves. 
Adventive eriophyoid mites in the United States of America

Several ornamental plants in the United States of America (USA) have been recently invaded by rust mites. One example, the bougainvillea rust mite, Phyllocoptes bougainvilleae Keifer (Fig. 1) was discovered in Florida (Welbourn 1995) and in California by Ochoa in 1997. Originally described from Brazil, this rust mite was discovered in Kenya and redescribed as Vittacus bougainvilleae by Abou-Awad (1991). This mite causes extensive edgerolling and rusting of the flowers and leaves, with the damage most severe in the white and pink bougainvillea varieties.

The coconut mite, A. guerreronis, is a well known pest of coconut, and was discovered in Florida in 1984 (Howard et al. 1990). In 2004 it was reported feeding on the meristematic tissue of queen palm ( $S$. romanzoffiana) seedlings in California nurseries (Ansaloni and Perring 2004) and causing necrosis, leaf distortion and plant death. Aceria guerreronis was also found on queen palm seedlings in some Florida nurseries by Welbourn in 2006 and 2008. This new host represents a serious threat for the ornamental palm business in Florida and California. Another adventive mite associated with monocotyledon plants is Aculodes duvius (Nalepa) which feeds on timothy grass, Phleum pretense L., and is actively moving from the western USA to the eastern USA (Lamp et al. 2007).

Due to their small size eriophyoids are easily moved around on plant material. For example, mangos are a commercial and dooryard crop in southern Florida and recent surveys of mangos have recently revealed four eriophyids [Diptilomiopus pamithus (Boczek \& Chandrapatya), Tegonotus mangiferae (Keifer), Spinacus pagonis Keifer and Aceria kenyae (Keifer; = Cisaberoptus kenyae)] not previously known from Florida and the USA (Welbourn 2005, 2008b, unpublished data). It is unknown how long these species have been in the USA, but they appear not be significant pests. A similar situation occurred on coconut palms in Florida where Acathrix trymatus Keifer (Phytoptidae) and three other genera (Scolocenus, Notostrix and Tumescoptes) were discovered for the first time in the USA (Welbourn 1996, 2007a, b).

Phyllocoptes fructiphilus Keifer is a native USA species that has jumped to multiflora rose, Rosa multiflora Thunb., an exotic Asian shrub that had become a serious invasive (Amrine 1996). In addition to feeding on multiflora rose, P. fructiphilus transmits Rose rosette disease (RRD; also called witches' broom of rose) to this invasive host, which has been an effective control (Amrine 1996). Efforts to manipulate P. fructiphilus for

Fig. 1 The bougainvillea rust mite, Phyllocoptes bougainvilleae Keifer, discovered in Florida (1995) and California (1997), USA

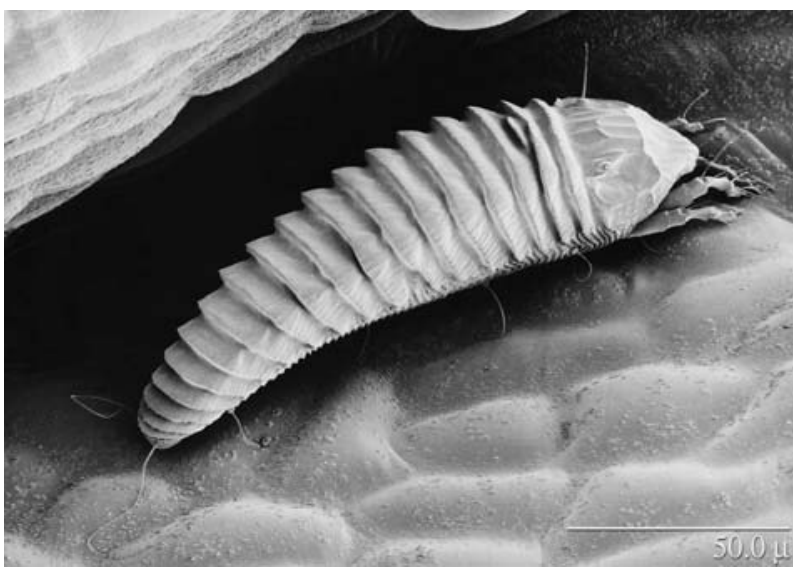


weed control are now underway (Epstein and Hill 1999). This system represents a case in which an endemic herbivore has transmitted an apparently native disease to an introduced weed. Under certain circumstances the mite can be a pest of ornamental roses, requiring chemical control (Amrine 1996). Aceria anthocoptes (Nalepa) is dispersing within the USA on Canadian thistle (Cirsium arvense (L.)) since it was first found in Maryland, in its bordering states, and in two northcentral states (Minnesota and North Dakota; Ochoa et al. 2001; Michels Jr et al. 2009). This mite can be considered an adventive species, in the recent colonized areas where dissemination has been favored by human activity.

The litchi erineum mite, Aceria litchii (Keifer), was introduced into Hawaii from Asia on Litchi chinensis Sonn. many years ago. Since then there have been two introductions of this mite into Florida from Hawaii on dormant trees. One discovered in 1955 which was declared eradicated in 1960 (Dekle 1957, 1960) and a second infestation in 1993 (Mead 1993). The successful eradication of an exotic eriophyoid is rare, but the use of quarantines and chemical control helped eradicate this mite from Florida. Dekle (1960) noted that the litchi trees were severely damaged by cold in late 1957 and that may have contributed to the eradication of the mite. No litchi erineum mites have been found in Florida since 1993. The litchi erineum mite before considered as a quarantine pest to Brazil (MAPA 2007) was recently reported in the country. Since July 2007 severe damage to newly developed leaves and fruits was observed in litchi orchards in the State of São Paulo and in April 2008 several A. litchi specimens were first collected and identified from Brazil (Raga et al. 2008). Control of this mite is expensive and difficult including pesticide application and pruning of trees that can reach $15-20 \mathrm{~m}$ tall. Introduction of the litchi erineum mite in Brazil could discourage litchi production that was in expansion.

Aceria zelkoviana Kim was introduced into Florida in 2000 on Zelkovia serrata (Thumb.) Mak. bonsai from China (Welbourn 2000), but it appears that this mite has not survived as no new records has been reported. The pink citrus rust mite, A. pelekassi was first reported from Florida in 1961 (Denmark 1962) and after the initial discovery an unsuccessful eradication program initiated. Welbourn (2008c) recently discovered Diptilomiopus assamica Keifer on citrus in Florida in association with the citrus rust mite, P. oleivora (Fig. 2). As with many of the exotic eriophyoids recently discovered in the USA, we have no data on the origin or when they were introduced into the USA. Many of these mites appear not to be pests, but leaf vagrants that entered into the USA on host plants that were poorly inspected or not treated for mites prior to entry into the USA.

The hibiscus erineum mite, Aceria hibisci (Nalepa), was described from Hibiscus rosa-sinensis L. (Malvaceae) in the Fiji islands and is a good example of an adventive mite in the USA, Australia and the Caribbean region. Feeding by this mite causes deformed young leaves and developing vegetative buds (Welbourn et al. 2008). Hara et al. (1996, 2001) reported A. hibisci in Hawaii, USA in 1989. In 1992 the mite was reported from Australia (Carson and Gough 2007). Quilici et al. (1997) reported A. hibisci from Hibiscus sp. in the Reunion Island. Aceria hibisci was first reported in the Caribbean region on the islands of Martinique in 1997 and Guadeloupe in 1998 and 2000 from Hibiscus rosa-sinensis and Hibiscus sp. (Flechtmann et al. 2000) and Flechtmann and Etienne 2001). De la Torre and Martinez (2004) reported the mite from Cuba on Talipaariti elatus (Sw.) Fryxell. (Malvaceae). Specimens from Dominica and Jamaica submitted to the Division of Plant Industry, FDACS, in 2007 and early 2008 were confirmed as A. hibisci (Welbourn 2008a). 
Fig. 2 The citrus rust mite, Phyllocoptruta oleivora (Ashmead), from citrus in Florida, USA

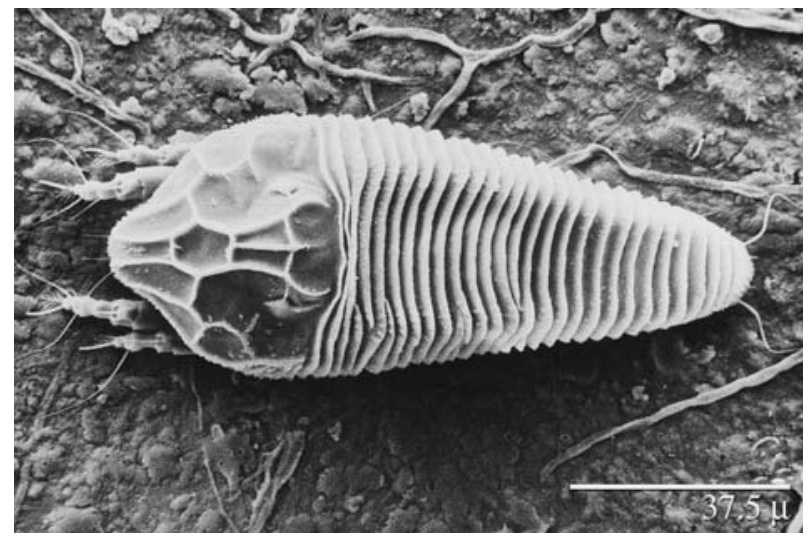

Eriophyoid invasions in mainland China

Hong et al. (2006) listed 25 adventive eriophyoid species in mainland China, 17 on fruit trees, three on forest and tea plants and three from vegetables and other crops (see Table 1). Some have caused considerable agricultural damage, while others are either potentially important economically or produce no damage. A classic and historical example of an invasive alien eriophyoid mite in China is the big bud mite, Cecidophyopsis ribis (Westwood) on blackcurrant, Ribes nigrum L. This mite is widely distributed in Europe; it was introduced into northeastern Heilongjiang Province, likely from neighboring Russia in the 1930-1940s, but was not reported until the 1980s (Bai 1987; Hong 1998). Other recent invasions into China include the rice rust mite, Cheiracus sulcatus Keifer, the tomato russet mite, A. lycopersici, and the apple rust mite, A. schlechtendali (Nalepa; Hong et al. 2006).

The rice rust mite was first described from rice in northern Thailand and southern India, apparently causing little or no damage (Keifer 1977, Mohanasundaram 1981). However, it caused serious damage to rice in northern Guangdong Provinces (Hong et al. 2005) and has spread to neighboring regions (Hong et al. 2006). Symptoms produced by the feeding of C. sulcatus is characterized by long rust stripes on the underside of rice leaves, visible under microscope, and withered and yellowed leaf tips visible to the naked eye. Hong et al. (2006) suggested this mite may have occurred around Shaoguan city for more than 2 years where it damaged many varieties of rice before spreading to other parts of the Province (Hong et al. 2006).

The tomato russet mite was first reported in China in 1983 on tomato, potato and tobacco (Kuang 1983), but no damage was documented until 1999. The first reports of damage were reported in greenhouses in Yunnan and Shangai Provinces (Chen et al. 2000, Kuang et al. 2000). Serious damage was also observed in tomatos in Shanghai greenhouses and shed houses in northeast China (Hebei Province; Jin and Liu 2001).

The apple rust mite was first reported in mainland China in 1995 (Kuang 1995) causing browning or rusting of the undersides of leaves. In heavily infested apple orchards in Sichuan Province, where $80-90 \%$ of apple trees were attacked resulting in little growth (Li and Cai 1996). Hong et al. (2006) reported that this mite is not yet widely distributed in China's major apple growing areas. 
The adventive wheat curl mite, Aceria tosichella, and associated viruses - a new threat to cereal crops in South America

Keifer described the wheat curl mite, A. tosichella, from wheat in Yugoslavia in 1969. This eriophyid has been reported from the main wheat production areas in North America, Europe, Asia, the Middle East, Africa and Oceania (Amrine and de Lillo 2006). Although A. tosichella occurs mainly in wheat, it can also develop in corn, sorghum, barley, oat, rye, pearl millet and in a large number of grasses of minor economic importance as well as various weeds (Jeppson et al. 1975; Amrine and de Lillo 2006). Yield losses to wheat crops due to A. tosichella infestations can reach 30\% (Harvey et al. 2002). However, the main damage is the transmission of Wheat streak mosaic virus (WSMV) and High plain virus (HPV; Oldfield and Proeseler 1996; Malik et al. 2003). WSMV is the etiological agent of one of the most important virus diseases of wheat causing major yield losses in North America, Europe, the Middle East, Oceania and Asia (Oldfield and Proeseler 1996; French and Stenger 2003; Sanchez-Sanchez et al. 2001). The HPV was first observed in 1993 in the High Plains subregion of the Great Plains in the central USA (Jensen et al. 1996). Mixed infections of WSMV and HPV have been observed in the USA making it difficult to estimate the losses associated with each virus. However, losses due to HPV infection in corn in some regions of the USA were estimated to be around 75\% (AQIS 2000). Other diseases associated with A. tosichella are Wheat spot mosaic virus (Jeppson et al. 1975) and Kernel Red Streak Agent (CABI 2002). Recently, two new A. tosichella transmitted viruses were reported: Brome streak mosaic virus in Europe (Stephan et al. 2008) and Triticum mosaic virus in the USA (de Wolf and Seifers 2008); no information is available on losses due to these virus infections.

In South America, the report of A. tosichella and its associated viruses is recent. WSMV was discovered in the Province of Buenos Aires, Argentina, in 2002 (Truol et al. 2004). Two years later its vector, A. tosichella, was also found in Argentina in association with WSMV infected plants (Navia et al. 2006). These reports drew attention to the possible distribution of the pathosystem A. tosichella/WSMV and HPV in the cereal production areas of Argentina's neighbors. A Pest Risk Analysis (PRA) for A. tosichella and WSMV/ HPV was conducted considering as risk areas the non-affected regions of Argentina and all territories of Brazil, Uruguay and Paraguay. The risk of introduction, establishment and economic importance of the pests in the risk areas was considered as high (Navia et al. 2007a, b).

Considering the high risk of $A$. tosichella and WSMV/HPV to Argentina, Brazil, Paraguay, and Uruguay, a joint project involving a multidisciplinary group of researchers from these countries was initiated in 2006. The main purpose of this project was to follow the status and dissemination of the pathosystem in the region, providing information on the distribution and hosts of $A$. tosichella and associated virus in the main wheat production areas of the forementioned countries.

In Brazil, the presence of A. tosichella was confirmed during 2006 surveys in the State of Rio Grande do Sul (Pereira et al. 2009), one of the main wheat production areas of the country on the border with Argentina. The mite was detected in both greenhouses and in the field. However symptoms due to A. tosichella infestations were observed only in greenhouse conditions. The wheat curl mite was exclusively found on wheat. The presence of WSMV has not yet been detected in Brazil (Pereira et al. submitted).

The occurrence of A. tosichella was also confirmed in Uruguay during surveys that covered most of the traditional agricultural and wheat production areas in November 2007 (Castiglioni and Navia 2009). During these surveys, A. tosichella was also found on 
ryegrass (Lolium multiflorum) and brome (Bromus unioloides), being the first report of the mite on other hosts grasses different from wheat in South America.

In Paraguay, a survey was conducted in 2007 which did not detect the presence of A. tosichella and associated virus (Espinoza 2008). Subsequent surveys are needed to continue monitoring the presence of $A$. tosichella and associated virus.

In Argentina, WSMV has spread to the main wheat production areas in at least seven Provinces-Santiago del Estero, Salta, Tucumán, La Pampa, Santa Fé, Córdoba and Buenos Aires (Truol et al. 2008). Severe WSMV epiphytes have been observed in wheat in the 2007 and 2008 growing seasons, especially in Balcarce, Buenos Aires Province (Truol and Sagadin 2008a; Truol et al. 2008). The presence of HPV was confirmed also in Argentina in 2007, in the Province of Buenos Aires in mixed infections with WSMV (Truol and Sagadin 2008b). At present, the pathosystem A. tosichella and WSMV/HPV is a threat to wheat production in Argentina because all wheat cultivars commonly used in Argentina, of short and intermediate cycles, are susceptible to the pathosystem (Bainotti and Vanzetti 2008).

Although WSMV and HPV have not yet been detected in Brazil, Uruguay and Paraguay, they are likely to soon extend their range into these countries given their proximity to the affected areas and intense movement of vehicles and cereal trade among these countries. The dissemination of $A$. tosichella and associated virus in the main production areas of wheat and winter cereal crops in countries of southern South America seems to be unavoidable. The knowledge of the monitoring and management practices for the A. tosichella/WSMV/HPV pathosystem gained by Argentinean technicians and researchers will surely help professionals in neighboring countries. Joint efforts should now be concentrated in search of resistant germplasm as well as continuing to follow the dissemination and status of the pathosystem in areas that are threatened by the mite and virus.

The coconut mite, Aceria guerreronis-invasion history, impact and the challenge for classical biological control

The recent spread of the coconut mite to most coconut production areas of the world has made this mite one of the most important coconut pests. Although described by Keifer (1965) there is evidence this mite was present in other areas in the Americas well before 1965 (Ortega et al. 1967; Robbs and Peracchi 1965; Zuluaga and Sánchez 1971). Symptoms characteristic of the mite have been observed in Colombia since 1948 (Zuluaga and Sánchez 1971), in Brazil since 1953 (Arruda personal communication) and in Mexico since 1960 (Ortega et al. 1967). By 1966 the mite was reported from the African Gulf of Guinea Islands and Benin in 1967 (Cabral and Carmona 1969; Mariau 1969). In the 1980s the mite was reported in Tanzania (Seguni 2002). Recent records place the coconut mite in Florida, USA in 1984 (Howard et al. 1990), California, USA in 1997 (Ansaloni and Perring 2004), South Asia (India and Sri Lanka) where the species was unknown until the end of the 1990s (Fernando et al. 2002; Sathiamma et al. 1998), and the Middle East (Oman; de Moraes personal communication).

The coconut mite is considered to be a serious pest of coconut palms throughout its geographical distribution (Moore and Howard 1996), causing significant crop losses. Populations develop in circular whitish areas covered by the perianth in the meristematic zone from which the growing coconut fruit expands. As the damaged surface expands from beneath the perianth and becomes exposed to air, it becomes suberized (i e., develops a brown cork-like surface with deep fissures). If intense mite feeding is concentrated on one side of the fruit meristem, growth of the fruit may be uneven, resulting in a distorted 
coconut. Severe damage results in stunted fruit (Mariau 1986, Howard and Moore 2008). High infestations have been reported ranging from 80 to $100 \%$ of coconut trees in some regions of Mexico (Ortega et al. 1967), 42-65\% in Cuba (Suarez 1991), 90\% in Costa Rica, 5-100\% in Sri Lanka (Fernando et al. 2000), and 20-70\% in India (Nair and Koshy 2000; Muthiah and Bhaskaran 2000). Reductions of near 30\% in copra yield have been reported in American and African countries (Hernandez Roque 1977; Julia and Mariau 1979; Moore 1986) and around 40\% in India (Nair and Koshy 2000; Muthiah and Bhaskaran 2000). Coconut fruit losses of approximately $70 \%$ have been reported in Venezuela due to premature dropping (Doreste 1968) and from 10 to $100 \%$ with an average of $21 \%$ in Tanzania and coastal islands (Mafia, Zanzibar and Pemba; Seguni 2002).

Coconuts are produced on about 26 million acres in 92 countries worldwide (FAO 2002), and considered to be the most important palm tree from the humid tropical regions and undoubtedly the most economically important plant in the family Arecaceae. In addition to its economic importance, it represents a relevant social crop due to the use of its products as a source of food, fiber, fuel, water, and shelter to communities (UGA 2009). The coconut mite represents a threat to coconut production worldwide. Although the coconut mite is widely distributed in most of the coconut production areas in Asia, Africa and the Americas, this mite has not yet reported from the main coconut production areas in the Philippines and Indonesia represent together more than $50 \%$ of world coconut production (FAO 2002).

Chemical measures used to control the coconut mite are expensive and difficult to apply because of colonies develop on the palms (Hernandez Roque 1977; Ramaraju et al. 2002). Acaricides must be applied frequently to control this mite. However, in most production areas, coconut is traditionally grown by small farmers who cannot afford the continuous application of insecticides/acaricides (Moore and Howard 1996; Muthiah and Bhaskaran 2000; Ramaraju et al. 2002). As an alternative, classical biological control has been considered as a promising strategy to mitigate populations of A. guerreronis (Moraes and Zacarias 2002).

Critical to the success of finding effective agents for biological control is the determination of the historical range of the mite. The true origin of the coconut mite remains uncertain since it was first reported almost simultaneously from both the Americas and Africa. To investigate the geographical origin, ancestral host associations, and colonization history of the mite, DNA sequence data from two mitochondrial and one nuclear region were obtained from samples from the Americas, Africa and the Indo-Oceanic region. Mitochondrial DNA 16S ribosomal sequences were most diverse in Brazil, which contained six of a total of seven haplotypes. A single haplotype was shared by the nonAmerican mites. Patterns of the nuclear ribosomal ITS variation were similar to those of the mitochondrial DNA, also with the highest nucleotide diversity found in Brazil. These results suggest an American origin of the mite and suggests the original host of the mite was a non-coconut palm. In contrast to the diversity in the Americas, all samples from Africa and Asia were identical or very similar, consistent with the hypothesis that the mite invaded these regions recently (Navia et al. 2005). These results have encouraged the prospect for finding biological control agents of A. guerreronis in the Americas (LawsonBalagbo et al. 2007a, b, 2008).

At present, international efforts supported by WOTRO, Netherlands Organization for Scientific Research are directed to the development of a classical biological control program for the invasive coconut mite in Africa and Asia: integrating biological, molecular and socioeconomic studies in the search and introduction of effective natural enemies. The primary objective of this project is to determine prospective natural enemies in the 
Americas and introduce them into Africa and Sri Lanka for the biological control of the coconut mite. In addition, the project will conduct studies to determine aspects of the biology and ecology of the coconut mite and the natural enemies selected for introduction, and determine the socioeconomic impact resulting from the intervention. The search for natural enemies will be focused in Brazil, Colombia, Mexico and Venezuela; the target countries for their introduction will be Benin, Tanzania and Sri Lanka. Researchers working on this project include those working at the ESALQ/University of São PauloBrazil, the University of Amsterdam in The Netherlands, the IITA in Benin, the Coconut Research Institute in Sri Lanka, and collaborators from Colombia, Mexico and Venezuela.

\section{Eriophyoid mites introduced as biological control agents of weeds: Could they become adventive species?}

In a technical sense, every eriophyoid that has been successfully introduced for biological control has become adventive, because it has established and spread in a new geographic region (Smith personal communication). Because most eriophyoid mite species are highly host specific, they have been considered ideal biological control agents for weeds (Rosenthal 1996). However, at present, few exotic species have been released in new regions due to increasing safety levels required for biocontrol agents and the relative lack of knowledge and practical experience using eriophyoids to control weeds (Smith et al. 2008). The potential risks associated with the release of exotic natural enemies have received attention (Howarth 1983, 1991) and an increasing number of countries are now applying risk assessment procedures before a new natural enemy can be imported and released. In the case of weed biological control programs, the effect of the natural enemy is not only determined on the target plant species, but also on native non-target species.

Negative environmental effects due to the release of eriophyoids have rarely been reported. The only case reported of an introduced species developing on non-target plants is Aculus hyperici (Liro). This mite is native to Europe and was introduced into Australia in 1991 to control Saint John's wort Hypericum perforatum L. Pre-release host specific trials indicated a low risk of impact on the native species Hypericum gramineum Forst. Although A. hyperici can colonize and develop on the native H. gramineum, apparently it has no significant impact on their growth or reproduction, either in the field or under glasshouse conditions (Willis et al. 2003).

Another possibility to be considered is that an eriophyoid introduced as a biological control agent becomes abundant and does not reduce the weed population. In this case it is possible that the mite could cause indirect nontarget effects by becoming an important part of a food web (Pearson and Callaway 2005).

\section{Pathways for eriophyoid mites}

There are many pathways for a species to be transported and released into new environments. Following Lockwood et al. (2007), a transport vector is the manner in which the species is carried along a pathway, and a pathway the route between the original region of a species and its release location. Pathways are also defined as any means, natural or "manmade", that allows the entry or spread of a pest (FAO 2006; Kahan 1989). Understanding the vectors and pathways is critical to comprehending the subsequent stages of an invasion process (Lockwood et al. 2007). Natural pathways appear to be a minor component of the 
global spread of non-indigenous species in contrast with human-mediated dispersal (NRC 2002).

The most important natural pathways for eriophyoid mites, for short and medium distances include wind, pollinators and water (Lindquist et al. 1996). Although mites actively initiate dispersal, it is a passive process resulting in their random deposition throughout the environment (Bergh 2001).

For long distances, most eriophyoid mites disseminate through human activity. Due to their biological and morphological traits the main pathways for eriophyoid mites are plants including any propagation material, fresh fruits, cut flowers, or bulbs.

There are examples of eriophyoid species that develop inside seeds and undoubtedly could disseminate through their movement. Trisetacus kirghsorum Shectchenko colonies develop inside Juniperus seed for 2 years, which corresponds with the duration of the ripening period of the seed (Oganezova and Pogosova 1994).

Is unclear whether the seeds of the host plants from which eriophyoid species do not develop inside of could be a pathway. For example, A. tosichella, a pest associated with cereal and grasses has been disseminated around the world. Cereal exchange and trade is exclusively done through seeds and processed material. Considering the large number of species of grass that are reported as hosts for the species, one hypothesis on the dissemination of A. tosichella is that it is transported on contaminant grasses accompanying potted ornamental plants infested with mites (Navia et al. 2006). Another hypothesis is that A. tosichella is disseminated through seeds. It is possible that in high mite populations in the field, or when mites are preparing for aerial dispersal at harvest time, some life stages could survive and accompany seeds during the transport period and colonize new areas where these seeds are planted. The interception of A. tosichella and Aceria zeala Keifer on wheat and corn germplasm seeds at the Laboratory of Plant Quarantine, Embrapa, Brazil (Navia and Flechtmann 2008) support the possibility of dissemination of these eriophyids on or in seeds. Additional evidence supporting the transport of an eriophyid mite on seeds was the detection of Aceria zeala L. (Fig. 3) on corn in a California greenhouse in July 2001. This was the first report of this potentially important pest of corn in North America. Potential hosts (corn and sorghum) surrounding the greenhouse were inspected but no mites were found (Ochoa and Amrine Jr 2007). This suggests the infestation started inside the greenhouse from mites on the seeds. Evidence exists that other phytophagous mites may disseminate through their host seeds, such as the case of the tarsonemid rice mite Steneotarsonemus spinki Smiley (Kane 2007).

It would be interesting to determine how long eriophyoid mites associated with seeds and grains are able to survive without feeding on fresh material under different environmental conditions, and if they can colonize new fields when seeds are germinating and growing. This information is important to the development of preventive measures to avoid the introduction of eriophyoid mites into new areas.

\section{Biosecurity and preventive measures to reduce the risk of eriophyoid mites}

Biosecurity encompasses all policy and regulatory frameworks to manage risks associated with food and agriculture, including relevant environmental risks (FAO 2001a). Biosecurity actions include protection and mitigation of factors related to bioinvasions.

Pest risk management is an analytical process for identifying risk mitigation options and for evaluating their efficiency, feasibility, and impacts (FAO 2001b). The options to mitigate risks in plant biosecurity include market restrictions, post-entry quarantine, 
Fig. 3 Aceria zeala Keifer, intercepted in California, USA greenhouse in July 2001
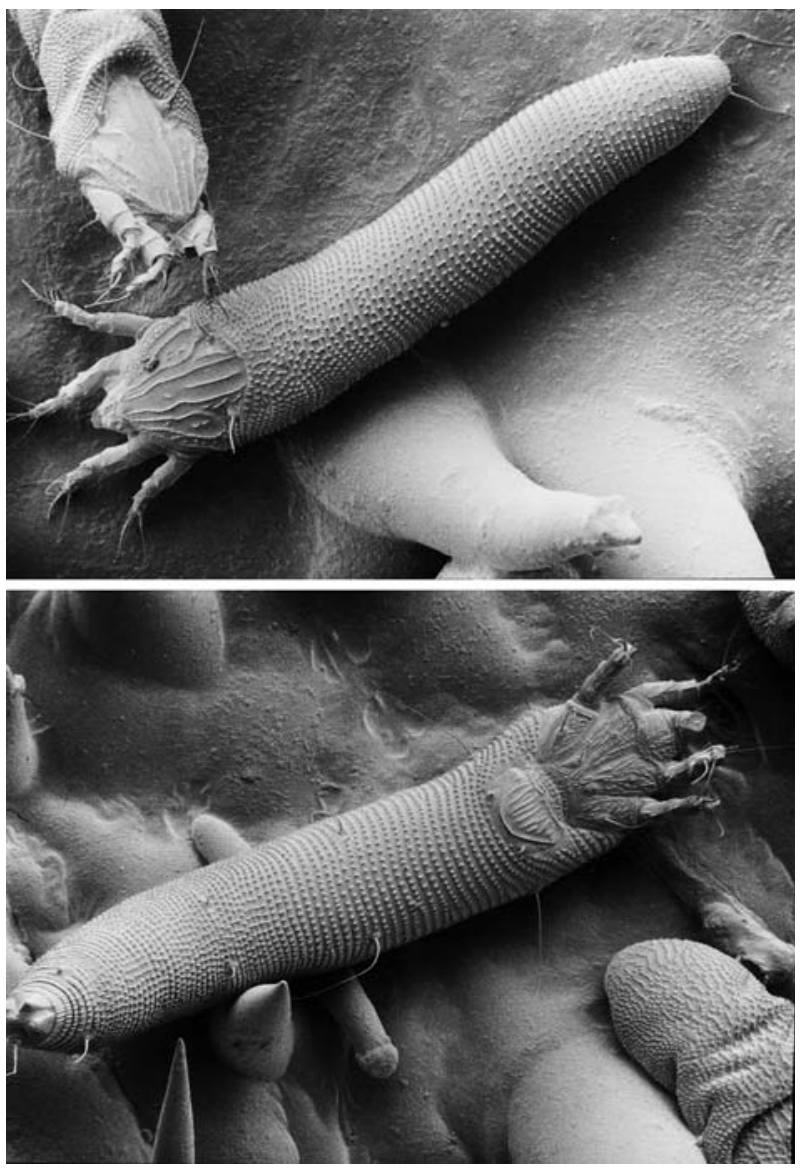

inspection at departure and entry points, quarantine treatments, transport conditions and pre- and postharvest procedures originating from pest-free or low incidence areas. Phytosanitary procedures should be selected according to the risk level represented by the importation of different commodities from different origins.

When eriophyoid mites represent a risk to agricultural and/or natural systems, it is important to concentrate efforts on measures that mitigate the risk of their entry and/or dissemination considering the difficulties and cost of eradication of phytophagous mites. Risk mitigation options for agricultural commodities, when eriophyoid mites are target pests are post-entry quarantine, quarantine treatments and origin from non-infested areas. Limitations of some mitigation measures are discussed below.

Inspection at departure and entry points and post-entry quarantine

The inspection of large cargoes for acarine species at entry or departure points is inefficient and is commonly used as a complementary procedure to other quarantine measures (Navia et al. 2007a). The reduced dimensions and sometimes the hidden location in the plant material decrease the likelihood that mites will be detected at their point of departure or upon their arrival at the point of entry. In the case of eriophyoid mites, both traits-reduced 
dimension and hidden location-can be extreme. The smallest phytophagous mites belong to this group and colonies can develop inside cracks, crevices, below bracts, sheath or even inside plant organs (for example buds, bulbs), which accentuates difficulties to their detection.

Inspections specifically aimed at the detection of eriophyoid mites usually focus upon symptoms resulting from their infestation such as plant abnormalities, discolorations, galls and blisters or necrotic spots. In that case, suspect plants are taken to the laboratory to identify the causal agent. This task is especially relevant in the case of eriophyoid mites that do not produce observable symptoms on the host plant or in the cases that the host plants present symptoms only if high infestations occur.

In countries that employ well-trained quarantine inspectors that detect mites, prepare material and take photos of relevant taxonomic characters for identification, the digital or remote identification system can be used as an important tool in plant biosecurity. A distance diagnostic system using digital imaging named Remote Pest Identification Program was implemented by Plant Protection and Quarantine, USDA, USA, in 1996 as a pilot project. The program provides advanced digital imaging technology and microscopy equipment to Plant Protection and Quarantine (PPQ) Identifiers and National Specialists at locations throughout the continental USA, Alaska, Hawaii, Puerto Rico and Guam. These tools facilitate the pest identification process by enhancing communication between port personnel and taxonomic experts allowing for faster processing of imported cargo at US ports of entry.

Imported plant material used for vegetative propagation is considered of high risk for many pests, including phytophagous mites. Post-entry quarantine, that is the official confinement of regulated articles after entry for observation and further inspection (FAO 2006), is the appropriate measure to avoid inadvertent pest introduction through importation of plant material for propagation. The time required to maintain the material under observation depends upon the bioecological characteristics of the target quarantine pest. For eriophyoid mites, which can develop inside plant organs, a lengthy period in post-entry quarantine may be required. Fruit species from arid regions usually are not imported as seeds, but through propagation material (budwoods, cuttings, rooted plants). To these arid fruit trees material Verma and Kapur (1990) have recommended glasshouse confinement for 1-3 seasons to detect latent infestations of eriophyoid mites. Also Dieckmann et al. (1994) have recommended at least 10 months of confinement for Ribes fruits. Another possible way to analyze samples is the use of destructive methods during inspection, such as the complete dissection of plant material, to assure the material is not infested with these mites.

Eriophyoid mite interceptions

International trade has long been recognized as a major pathway by which adventive species arrive to and colonize new geographical ranges. Recent reviews have noted the importance of intercepting these species at the border, before they have the opportunity to become established in new countries (NRC 2002). Information on intercepted pests associated with specific commodities is relevant when conducting a pest risk assessment (PRA). Interception of a new pest on an imported commodity is a prerequisite to initiating a PRA. Also, information on the frequency of interception of a specific pest is required during entry risk evaluation (FAO 2006).

Comparing information available in the scientific literature regarding interceptions of eriophyoid mites versus that of adventive insects or other groups of phytophagous mites, 
the former is strikingly scarce and difficult to find. Examples of eriophyoids intercepted at the borders include the gardenia bud mite, Colomerus gardeniella (Keifer), which lives in the petiole bases on Gardenia jasminoides Ellis. The mite is native to Mexico and was first intercepted in 1964 in California (Dekle and Denmark 1970) and later found in other states including Hawaii. Phyllocoptes acuminatus Manson was intercepted in New Zealand several times on Codiaeum sp. [Euphorbiaceae] from Samoa and Fiji islands, but is not believed to be established there (Manson 1972).

The dry bulb mite A. tulipae is able to develop on several plant species in the families Alliaceae and Liliaceae. In the genus Allium, its hosts include species such as shallot, onion and garlic and is also known to occur on tulips (Tulipa). It is considered one of the most important eriophyoid pests not only because the direct damage on plant but also for its capacity to vector several important viruses such as the Onion mite-borne latent virus and the Shallot mite-borne latent virus (Perring 1996, Oldfield and Proeseler 1996). This mite is widespread in Europe although it does not occur in the United Kingdom where it was recently detected on infested onion (Allium cepa) bulbs used for planting, originating from The Netherlands (Ostoja-Starzewski and Matthews 2006). Due to their economic importance, a pest risk analysis (PRA) was performed in the UK in 2007 to assess the invasive potential of this pest and the economic consequences of establishment. Even though the PRA considered that the mite is capable of establishing both outdoors and in storage facilities, significant damage is not expected in the UK and no phytosanitary measures were recommended (MacLeod 2007). Aceria tulipae has also been intercepted in Japan on infested shallots originating from France and the USA (Masaki 1991).

Inspections of seeds, bulbs, seedlings and tubers of cultivated plants conducted at the Laboratory of Plant Quarantine (Embrapa) in Brasilia, Brazil, from 2004 to 2008, revealed the presence of five exotic eriophyid species: A. hystrix and A. tosichella were intercepted on wheat seeds, A. zeala on corn seeds, A. fockeui from cherry stakes, and Oxycenus maxwelli (Keifer) from olive seedlings. All interceptions included live forms of the mites, even surprisingly those from wheat and corn seeds (Navia and Flechtmann 2008).

\section{Quarantine treatments and eriophyoid disinfestation}

For a quarantine treatment to be acceptable all organisms associated with the plant material must receive lethal doses and the material cannot be damaged. In fact, only a few treatments have achieved the high control levels required to be used as a quarantine treatment (MacDonald and Mills 1994). Sometimes postharvest treatments that reduce pest populations are accepted as phytosanitary measures by plant protection organizations if associated with other mitigation options.

A quarantine treatment that has been used on the commercial level for mite disinfestation of fresh plant products is fumigation with methyl bromide (MB). MB fumigation is an extremely toxic treatment that requires special safety facilities, which in some countries is not available for large volumes of commercial material. MB has been evaluated for mite disinfestation of several species/commodities, especially fresh fruits (Katayama et al. 2001). There is little information specific for the disinfestation of eriophyoid mites through MB fumigation. For eriophyoid and other mites infesting bulbs, there are instructions that MB fumigation should be repeated after 10-14 days to kill the eggs (Mackie et al. 1942).

Development of alternative quarantine treatments is important to prevent disruption of international trade and to allow access to new markets. Mite disinfestation studies include controlled atmosphere and irradiation experiments and thermal treatments. 
Controlled Atmosphere Treatments (CAT) consists of modifications of carbon dioxide concentration in closed environments which become lethal to the pests. The feasibility of CATs storage to provide quarantine security has been demonstrated for the apple rust mite, A. schlechtendali and the European red mite, Panonychus ulmi Koch. Eggs are killed in 5.3 months when apples are stored at $2.8^{\circ} \mathrm{C}$ in an atmosphere of $1 \% \mathrm{O} 2$ and $1 \% \mathrm{CO} 2$ without detrimental effects to the apples. A possible disadvantage of this treatment may be the length of storage exposure required for sufficient mortality (Lidster et al. 1981). Authors consider that low $\mathrm{O} 2$ storage probably would not replace pre-storage fumigation but may provide a complementary technique for exported apples held for long periods of time.

Irradiation is a viable quarantine treatment which has been studied for over 40 years, although it is of little commercial use. The commercial use and almost all evaluations have been directed toward fruit flies. The two principal obstacles to its commercial application are the fact that the pests are not immediately killed and the need for the development of approved protocols by government regulatory agencies. The measures of efficiency of irradiation to mite disinfestation treatments should rely on the prevention of adult emergence, when only eggs and larvae are present, or sterility, when immatures or adults are present (this is the case of mites), and not on pest absence or mortality. This can be accomplished with relatively low doses that are tolerated by many fruits. In insects, usually females are more susceptible to radiation-induced sterility than males while for Tetranychoidea mites the opposite has been observed. It has been found that the dose of radiation necessary to control Lepidoptera and most mites is about $300 \mathrm{~Gy}$, which is higher than the dose necessary to control several other pest groups. Irradiation has been evaluated for the control of some Tetranychoidea species (Dohino and Tanabe 1994; Majumder et al. 1996 Lester et al. 1997). For eriophyoid mites little or no useful data is available (Molins 2001). Future research should concentrate on evaluating doses for other important groups of organisms including eriophyoid mites (Hallman 1998).

Thermal treatments for eriophyoid mites have been recommended for containment and could be used as a complementary mitigation option. For A. tulipae disinfestations, a hot water treatment of bulbs $\left(55^{\circ} \mathrm{C}\right.$ for $10-20 \mathrm{~min}$, or $60^{\circ} \mathrm{C}$ for $\left.10-15 \mathrm{~min}\right)$ can reduce mite populations although it may also reduce bulb germination. A post harvest treatment consisting of drying the bulbs can also reduce populations (MacLeod 2007).

\section{Challenges}

There are no doubts that eriophyoid mites represent a group of high potential as AMS. Economic, social and environmental impact due to invasion of some species of eriophyoid mites has been notorious. However, these organisms have received little attention from agriculture or environmental agencies. It would be important to raise public awareness of the risk and importance of these tiny organisms as AMS. Perhaps an important step would be quantifying losses caused by adventive eriophyoids. This is not an easy task for any mite pest. Collaboration of economists with a wide perception of environmental impact would be crucial.

Scientific aspects of eriophyoid invasion processes have not been explored. Understanding ecological and genetic aspects of eriophyoid invasions could help to define mitigation measures and management strategies. Knowledge of host specificity and adaptation to new host plants of eriophyoid species could be useful in risk evaluation and in guiding the adoption of control measures (see Michalska et al. 2009). Phylogeography 
studies using molecular data could provide information on the origin and colonization routes of invasive eriophyoids, a necessity for guiding adoption of quarantine measures and prospection of biological control agents (Navajas and Navia 2009). Knowledge of the invasion genetic process and biological response to new environmental parameters would help in understanding and previewing population explosions of adventive eriophyoids.

Accurate species identification is a key challenge in the detection and monitoring of adventive species. Scarce information on intercepted eriophyoid mites, crucial in PRA and other biosecurity actions, is primarily a result of the deficiency of Eriophyoidea taxonomists. In decisive instances, lack of information about the correct identity of the mite, to which is associate information on its biology and ecology have caused serious consequences (Ochoa 2005). A deficiency in taxonomic capability is a general problem for most groups of organisms and has been recognized as an impediment (named "taxonomic impediment") to implementing the convention on biological diversity (CBD) in reference to the action of "prevent the introduction of, control or eradicate those alien species which threaten ecosystems, habitats or species" (CBD 2002). The global taxonomy initiative (GTI) was set up under the Convention to overcome the 'taxonomic impediment'. Its main objectives are to reduce the knowledge gaps in our taxonomic system, the shortage of trained taxonomists and curators and, thereby, to improve decision-making in conservation. This initiative aims to providing relevant taxonomic information for custom and quarantine services on invasive alien species at national and regional levels. Molecular techniques can be extremely helpful in the diagnosis of species and characterization of subspecific taxonomic levels in Eriophyoidea giving support to biosecurity actions (Navajas and Navia 2009).

Research on eriophyoid disinfestation treatments is needed. Presently the options for mite disinfestation of commercial material are scarce. Development of integrated measures for system approaches to minimize risks related to eriophyoid mites is desirable considering the low efficiency of the inspection of commercial material to prevent mite introduction and the frequent inefficacy of single treatments to achieve the security level required. A system approach integrates pest risk management measures to meet the appropriate level of phytosanitary protection and consist in the use of two or more measures that are independent of each other (FAO 2002).

Adventive eriophyoid mites have not been well documented in China (Hong et al. 2006). This observation can be generalized to other countries. Surely a large number of adventive eriophyoids has not been reported as such or if reported have not been listed for official agencies. It would be important to include adventive eriophyoids in official lists aiming to call attention to the need for adoption of preventive or control measures directed to them. Also the development of databases on adventive eriophyoid mites would be desirable, detailing information on known and potential invasive species, taxonomy, native and introduced ranges, biology, physiology, impacts, pathways for introduction and spread and prevention and control methods.

Acknowledgments We thank Drs. Greg Evans (APHIS-USDA), Gary Miller (USDA-SEL), Jim Amrine (University of West Virginia) and Eddie Ueckermann (Agricultural Research Council, South Africa) for review and helpful comments on the manuscript. To Dr. Lincoln Smith for valuable suggestions and revision of the text related to the potential of weed control eriophyoids as adventive species. To Dr. Gary Bauchan and Mr. Eric Erbe, USDA-ECMU kindly provided for the low temperature scanning electron microscope photos of several species of Eriophyidae. To Peter Touhey and Geoff White (USDA) supplied species list data for the USA. To CNPq for the research fellowship to the first author. 


\section{References}

Altieri M, Rojas A (1999) Ecological impacts of Chile's neoliberal policies, with special emphasis on agroecosystems. Environ Dev Sustain 1:55-72

Amrine JW Jr (1996) Phyllocoptes fructiphilus and biological control of multiflora rose. In: Lindquist EE, Sabelis MW, Bruin J (eds) Eriophyoid mites: their biology. natural enemies and control. Elsevier, The Netherlands, pp 741-750

Amrine JW Jr, de Lillo E (2006) Database on Eriophyoidea (Acarina: Prostigmata) of the world. Filemaker 4.0. West Virginia University, USA

Angeli G, Rizzi C, Dorigoni A, Ioriatti C (2007) Population injury levels of the apple rust mite Aculus schlechtendali (Nal.) on Golden Delicious and Red Delicious apple fruits. Bull OILB/SROP 30: 255-260

Ansaloni T, Perring TM (2004) Biology of Aceria guerreronis (Acari: Eriophyidae) on queen palm. Int J Acarol 28:121-146

AQIS Australian quarantine \& inspection service (2000) Import risk analysis for the importation of bulk maize (Zea mays L.) from the United States of America. Department of Agriculture, Fisheries and Forestry, Australia. http://www.daff.gov.au/_data/assets/pdf_file/0012/20901/rev_dft_ira_maize.pdf. Accessed on 10 Oct 2008

FIAS (2009). Forest invasive alien species Canada. Galls of hardwoods. www.exoticpests.gc.ca. Accessed on 7 Apr 2009

Bai RX (1987) Blackcurrant mite. North Hort 2:25-26

Bainotti C, Vanzetti L (2008) Perspectivas para el mejoramiento de trigo en la búsqueda de resistencia a Wheat streak mosaic virus (WSMV) en américa del Sur. In: Workshop en virosis de cereales transmitidas por el ácaro Aceria tosichella—Wheat streak mosaic virus y High plain virus—en los países del Cono Sur: situación, detección y manejo, Balcarce, Argentina. Libro de Resúmenes. INTA-IFFIVE. pp: 9

Bergh JC (2001) Ecology and aerobiology of dispersing citrus rust mites (Acari: Eriophyidae) in Central Florida. Environ Entomol 30:318-326

Carson C, Gough N (2007) Hibiscus erinos mite. Accessed 9/1/2009 from http://www.dpi.qld.gov.au/ cps/rde/xchg/dpi/hs.xsl/26_8327_ENA_HTML.htm

CAB International (2002) Crop Protection Compendium. Wallingford. 1 CD-ROM

Cabral RVG, Carmona MM (1969) Aceria guerreronis Keifer (Acarina: Eriophyidae), uma espécie nova para S. Tomé e Príncipe. Portugaliae Acta Biológica 10:353-358

Carson C (2000) Hibiscus erinose mite. In: The world of Hibiscus. Hibiscus pests and diseases. http://www.hibiscusworld.com/pests-and-diseases.html. Accessed on 12 Mar 2009

Castagnoli M (1996) Ornamental coniferous and shade trees. In: Lindquist EE, Sabelis MW, Bruin J (eds) Eriophyoid mites: their biology, natural enemies and control. Elsevier, The Netherlands, pp 33-88

Castagnoli M, Oldfield GN (1996) Other fruit trees and nut trees. In: Lindquist EE, Sabelis MW, Bruin J (eds) Eriophyoid mites: their biology, natural enemies and control. Elsevier, The Netherlands, pp 543-559

Castagnoli M, Simoni S, Panconesi A, Failla O (2002) Susceptibility of cypress seedlings to the eriophyoid mite Trisetacus juniperinus. Exp Appl Acarol 26:195-207

Castiglioni E, Navia D (2009) Presence of the Wheat Curl Mite, Aceria tosichella Keifer (Prostigmata: Eriophyidae) in Uruguay. Agrociencia (in press)

CBD (2002) Alien species that threaten ecosystems, habitats or species. In: sixth conference of the parties (COP 6), Decision VI/23. The Hague, The Netherlands. http://www.cbd.int/decisions/. Accessed on 14 Dec 2008

Chagas CM, Rossetti V, Colariccio A, Lovisolo O, Kitajima EW, Childers CC (2001) Brevipalpus mites (Acari: Tenuipalpidae) as vectors of plant viruses. In: Halliday RB, Walter DE, Proctor H, Norton RA, Collof M (eds) Acarology: proceedings of the X international congress. CSIRO Publishing, Melbourne, pp 369-375

Chen B, Luo YZ, Yin SG (2000) New pest of tomato, Aculops lycopersici. Yunnan Agri. Sci and Tech. 2:32-33

DAISIE (2009) Handbook of alien species in Europe. Springer, The Netherlands

Childers CC, Kitajima EW, Welbourn WC, Rivera C, Ochoa R (2001) Brevipalpus mites on citrus and their status as vectors of citrus leproses. Manejo Integrado de Plagas 60:66-70

De la Torre PE, Martinez H (2004) Lista de los acaros eriofioides (Acari: Prostigmata: Eriophyoidea) de Cuba. Revista Iberica de Aracnologia 9:123-126

de Lillo E (2004) Fauna Europaea: Acari, Eriophyoidea. In: Karsholt O and Nieukerken, EJ van (eds) Fauna Europaea version 1.3. Avalaible at: http://www.faunaeur.org. Accessed on 04 Apr 2009 
de Oliveria CAL, Eschiapapti D, Velho D, Sponchiado OJ (1982) Quantitative losses caused by the tomato russet mite, Aculops lycopersici (Massee, 1937) in tomato (Lycopersicon esculentum Mill.). Ecossistema $7: 14-18$

de Wolf E, Seifers D (2008) Triticum mosaic: a new wheat disease in Kansas. Kansas State University Agricultural Experiment Station and Cooperative Extension Service. EP-145, August 2008, p 2

Dekle GW (1957) Twenty-first biennial Report for the period July1, 2954-June 30, 1956. State Plant Board of Florida 2, Bulletin 11-A: 71-75

Dekle GW (1960) Twenty-third biennial Report for the period July1, 1958-June 30, 1960. State Plant Board of Florida 2, Bulletin 14: 65-70

Dekle GW, Denmark HA (1970) An eriophyid mite, Eriophyes gardeniella Keifer, on gardenia (Acarina, Eriophyidae). Entomology circular n 100. Fl Dept Agric \& Cons Serv. Division of Plant Industry. p 2

Denmark HA (1962) Aculus pelekassi Keifer, Another citrus mite in Florida. Proc Fla State Hort soc 75: 25-27

di Castri F (1990) On invading species and invaded ecosystems: the interplay of historical chance and biological necessity. In: di Castri F, Hansen AJ, Debussche M (eds) Biological invasions in Europe and Mediterranean Basin. Kluwer, The Netherlands, pp 3-16

Dieckmann M, Frison EA, Putter T (1994) FAO/IPGRI technical guidelines for the safe movement of small fruit germplasm. Rome. vol 2

Dohino T, Tanabe K (1994) Electron beam irradiation of immature stages and adult males of two spotted spider mite, Tetranychus urticae Koch (Acari: Tetranychidae). Res Bull Plant Prot Serv Jpn 30:27-34

Doreste SE (1968) El ácaro de la flor del cocotero (Aceria guerreronis Keifer) en Venezuela. Agronomia Tropical 18:370-386

Easterbrook MA (1996) Damage and control of eriophyoid mites in apple and pear. In: Lindquist EE, Sabelis MW, Bruin J (eds) Eriophyoid mites: their biology, natural enemies and control. Elsevier, The Netherlands, pp 527-541

Epstein AH, Hill JH (1999) Status of rose rosette disease as a biological control for multiflora rose. Plant Dis 83:92-101

Espinoza N (2008) Muestreo y diagnóstico de presencia del ácaro Aceria tosichella Keifer en gramíneas en Paraguay. In: Workshop en virosis de cereales transmitidas por el ácaro Aceria tosichella—Wheat streak mosaic virus y High plain virus en los países del Cono Sur: situación, detección y manejo. Balcarce, Argentina. Libro de Resúmenes. INTA-IFFIVE, pp 19-20

FAO (2001a) Biosecurity in food and agriculture. In: sixteenth session committee on agriculture, Rome, March 26-30 2001. http://www.fao.org/docrep/meeting/003/x9181e.htm. Accessed Apr 2009

FAO (2001b). Pest risk analysis for quarantine pests. International Standard for Phytosanitary Measures (ISPM): Publication No. 11

FAO (2002) The use of integrated measures in a systems approach for pest risk management (ISPM): Publication No. 14

FAO (2006) Glossary of Phytosanitary terms. Secretariat of the International Plant Protection Convention of the Food and Agriculture Organization (FAO) of the United Nations. ISPM No 5

Fernando LCP, Wickramananda IR, Aratchige NS (2002) Status of coconut mite, Aceria guerreronis in Sri Lanka. In Fernando LCP, Moraes GJ de, Wickramananda IR (eds) Proceedings of the international workshop on coconut mite (Aceria guerreronis), Lunuwila. Coconut Research Institute, pp 1-8

Flechtmann CHW, Etienne J (2001) Plant mites from Guadeloupe and French Guyana with descriptions of five new species of eriophyid mites (Acari: Eriophyidae, Tenuipalpidae, and Tetranychidae). Int $\mathbf{J}$ Acarol 27(4):261-270

Flechtmann CHW, Kreiter S, Etienne J, de Moraes G (2000) Plant mites (Acari) of the French Antilles. 4. Eriophyidae (Prostigmata). Acarologia 40(3):321-342

Fournier V, Rosenheim JA, Johnson M, Brodeur J, (2001) When two invasive pests meet: Rust mite and powdery mildew interactions on papaya. Entomol Soc Am 2001 Annual Meeting

French R, Stenger DC (2003) Evolution of Wheat Streak Mosaic Virus: dynamics of population growth within plants may explain limited variation. Ann Rev Phytopath 41:199-214

Glavendekić M, Mihajlović L, Petanović R (2005) Introduction and spread of invasive mites and insects in Serbia and Montenegro. Proceedings Plant protection and plant health in Europe: introduction and spread of invasive species. Alford DV, Backhaus GF (ed) Berlin, Germany

Gólya G, Kozma E (1998) New data on the apple rust mite (Acari: Eriophyidae). Folia Entomol Hung 59:235-239

Hallman G (1998) Ionizing radiation quarantine treatment. Ann Soc Entomol Brasil 27:313-323

Hara A, Tsuda, D, Tavares J, Yogi J, Hensley D (1996) Hibiscus erineu mite. Univerity of Hawaii at Manoa, Cooperative Extension Service, Insect Pests, Instant Information Series No. 18

Hara A, Tsuda, D, Tavares J, Yogi J, Hensley D (2001) Hibiscus erineum mite. University of Hawaii at Manoa, Cooperative Extension Service, Insect Pests, IP-7 
Harvey TL, Martin TJ, Seifers DL (2002) Wheat yield reduction due to Wheat Curl Mite (Acari: Eriophyidae) infestations. J Agric Urban Entomol 19:9-13

Helle W, Wysoki M (1996) Arrhenotokous parthenogenesis. In: Lindquist EE, Sabelis MW, Bruin J (eds) Eriophyoid mites: their biology, natural enemies and control. Elsevier, The Netherlands, pp 169-172

Hernandez Roque F (1977) Combate químico del eriófido del cocotero Aceria (Eriophyes) guerreronis (K.) en la Costa de Guerrero. Agricultura Técnica en México 4:23-38

Hong XY (1998) Proceedings of blackcurrant mite research. Entomol Knowl 35:185-188

Hong XY, Xue XF, Zhou YJ, Tong GY (2005) Cheiracus sulcatus, a newly found invasive eriophyoid mite damaging rice in Guang-dong Province, south china. Acta entomol Sinica 48:279-284

Hong XY, Wang DS, Zhang ZQ (2006) Distribution and damage of recent invasive eriophyoid mites (Acari: Eriophyoidea) in mainland China. Intern J Acarol 32(3):227-240

Howard FW, Moore D (2008) A coconut mite, Aceria guerreronis Keifer (Arachnida: Acari: Eriophyidae). University of Florida, IFAS extension. Publication EENY-398, p 7. http://edis.ifas.ufl.edu/IN709. Accessed 11 Apr 2009

Howard FW, Abreu-Rodriguez E, Denmark HA (1990) Geographical and seasonal distribution of the coconut mite, Aceria guerreronis (Acari: Eriophyidae), in Puerto Rico and Florida, USA. J Agric, University of Puerto Rico 74: 237-251

Howarth FG (1983) Classical biocontrol: panacea of Pandora's Box? Proc Haw Ent Soc 24:239-244

Howarth FG (1991) Environmental impacts of classical biological control. Annu Rev Entomol 36:485-509

Jensen SG, Lane LC, Seifers DL (1996) A new disease of maize and wheat in the high plains. Plant Dis 80:1387-1390

Jeppson LR, Keifer HH, Baker EW (1975) Mites injurious to economic plants. Univ. California Press, Berkeley

Jin HF, Liu YZ (2001) The occurrence of tomato russet mite in shed houses in Yongqing County. Hebei Agri 8:28

Jones AT (1999) Eriophyid mite transmitted viruses and virus-like agents of plants. In: biotic interactions in plant-pathogen associations. BSPP Presidential Meeting, British Society for Plant Pathology. Oxford. http://www.bspp.org.uk/archives/bspp1999/session5.php. Accessed 07 Apr 2009

Julia JF, Mariau D (1979) Nouvelle recherches en Côte-d'Ivoire sur Eriophyes guerreronis K., acarien ravageur des noix du cocotier. Oléagineux 34:181-187

Kahan RP (1989) Plant protection and quarantine, v.1: biological concepts. CRC Press, Boca Ratón, p 226

Kane EC (2007) Detection and identification of the rice mite Steneotarsonemus spinki Smiley (Acari: Tarsonemidae). USDA-APHIS. Riverdale. 4p. http://www.aphis.usda.gov/plant_health/plant_pest_ info/rice_mite/downloads/s_spinki_guide.pdf. Accessed Apr 2009

Katayama M, Mizutani K, Kishino H, Yabuta S, Tomita I, Mizuno T, Yoneda M, Soma Y, Kawakami F (2001) Mortality tests for kanzawa spider mite, six-spotted mite, tropical citrus aphid and citrus psylla on Satsuma mandarins by methyl bromide fumigation. Res Bull Plant Prot Serv Jpn 37:27-33

Keifer HH (1965) Eriophyid studies B-14. Sacramento, California Department of Agriculture, Bureau of Entomology

Keifer HH (1977) Eriophyid studies C-13. Agr Res Svc USDA. 24

Keifer HH, Baker EW, Kono T, Delfinado M, Styer WE (1982) An illustrated guide to plant abnormalities caused by eriophyid mites in North America. USDA. Agric. Handbook n. 573, p 178

Kenis M, Auger-Rozenberg MA, Roques A, Timms L, Péré C, Cock MJW, Settele J, Augustin S, LópezVaamonde C (2009) Ecological effects of invasive alien insects. In: Langor DW, Sweeney J (eds) Ecological impact of non-native invertebrates and fungi on terrestrial ecosystems. Springer, The Netherlands, pp 21-45

Koehler CS, Allen WW, Costello LR (1985) Fuchsia gall mite management. Calif Agric 39(7-8):10-12

Kozlowski J, Boczek J (1987) Overwintering of the apple rust mite Aculus schlechtendali (Nal.) (Acarina: Eriophyoidea). Prace Naukowe Instytutu Ochrony Roslin 29:51-62

Kuang HY (1983) Two new species and one new record of eriophyid mites from China. Acta Zootax Sinica 8:389-391

Kuang HY (1995) Acari: Eriophyoidea (1) Economic insect fauna of China. No. 44. Science Press, Beijing

Kuang KY, Wang DS, Yuan YD, Zhang FQ, Wu SC (2000) Major pests and diseases of tomato and their control in modern greenhouses. Acta agric. Shangai: 6-9

Lamp W, Dively G, Ochoa R (2007) Mites. In. Lamp WO, Berberet RC, Higley L, Baird CR (eds) Handbook of forage and rangeland insects. Entomological Society of America, pp. 81-83

Lawson-Balagbo LM, Gondim MGC Jr, de Moraes GJ, Hanna R, Schausberger P (2007a) Life history of the predatory mites Neoseiulus paspalivorus and Proctolaelaps bickleyi, candidates for biological control of Aceria guerreronis. Exp Appl Acarol 43:49-61 
Lawson-Balagbo LM, Gondim MGC Jr, deMoraes GJ, Hanna R, Schausberger P (2007b) Refuge use by the coconut mite Aceria guerreronis: fine scale distribution and association with other mites under the perianth. Biol Control 43:102-110

Lawson-Balagbo LM, Gondim MGC Jr, deMoraes GJ, Hanna R, Schausberger P (2008) Exploration of the acarine fauna on coconut palm in Brazil with emphasis on Aceria guerreronis (Acari, Eriophyidae) and its natural enemies. Bull Entomol Res 98:83-96

Lester PJ, Dentener PR, Bennett KV, Connolly PG (1997) Postharvest disinfestation of diapausing and nondiapausing twospotted spider mite (Tetranychus urticae) on persimmons: hot water immersion and cool storage. Entomol Exp et Appl 83:189-193

Li Q, Cai R (1996) Occurrence and damage of the apple rust mite Aculus schlechtendali. Plant Prot 22: $16-17$

Lidster PD, Sanford KH, McRae KB (1981) Effects of modified atmosphere storage on overwintering populations of the apple rust mite and European red mite eggs. HortScience 16:328-329

Lindquist EE, Amrine JWJ (1996) Systematics, diagnoses for major taxa, and keys to families and genera with species on plants of economic importance. In: Lindquist EE, Sabelis MW, Bruin J (eds) Eriophyoid mites: their biology, natural enemies and control. Elsevier, The Netherlands, pp 33-88

Lindquist EE, Sabelis MW, Bruin J (1996) Eriophyoid mites: their biology, natural enemies and control. World Crop Pests, vol 6. Elsevier, The Netherlands

Lockwood J, Hoopes M, Marchetti M (2007) Invasion ecology. Blackwell Publishing, UK

MacDonald O C, Mills, KA (1994) Plant quarantine treatments: are there alternatives to methyl bromide? P:183-189. In Proceedings Crop Protection Conference-Pests and Diseases. Brighton. Nottingham: Major Print, 1

Mackie DB, Steinweden JB, Carter WB (1942) Methyl bromide fumigation 1942 of narcissus bulbs for the control of bulb flies and bulb mites. Sacramento, California. Dpt Agriculture. www.fao.org/docrep/ X5042E/x5042E0z.htm. Accessed 12 Mar 2009

MacLeod L (2007) CSL Pest Risk Analysis for Aceria tulipae. www.defra.gov.uk/planth/pra/Aceriatulipae. pdf. Accessed on 15 Mar 2009

Majumder MZR, Bhuiya AD, Chowdhury N (1996) Effects of radiation on mortality, fecundity and sterility of Oligonychus biharensis (Hirst) infesting common flower plants in Bangladesh. Bangladesh J Zool 24:25-32

Malik R, Brown-Guedira GL, Smith CM, Harvey TL, Gill BS (2003) Genetic mapping of wheat curl mite resistance genes $\mathrm{Cmc} 3$ and $\mathrm{Cmc} 4$ in common wheat. Crop Sci 43:644-650

Mansilla JP, Pérez Otero R, Salinero C, López Villarreal MJ, Barrote CR, Meira M (2003) The distribution of eriophyid mites and its presence on Camellias in Galicia and Portugal. Bol San Veg Plagas 29:35-41

Manson DCM (1972) New species and new records of eriophyid mites (Acarina: Eriophyidae) from New Zealand and the Pacific area. Acarologia 14:351-360

MAPA Ministério da Agricultura, Pecuária e Abastecimento (2007) Instrução normativa 52. http://www. extranet.agricultura.gov.br/sislegis-consulta/18316. Accessed 06 Mars 2009

Mariau D (1969) Aceria guerreronis Keifer: récent ravageur de la cocoteraie Dahoméenne. Oléagineux 32:101-111

Mariau D (1986) Comportement de Eriophyes guerreronis Keifer à l',egard de différentes variétés de cocotiers. Oléagineux, 41: 499-505.Schiliesske J (1988). On the gall mite fauna (Acari: Eriophyoidea) of Cocos nucifera L. in Costa Rica. Nachrichtenblatt des deutschen Pflanzenschutzdienstes, 40: 124-127

Masaki M (1991) A list of Acarina intercepted in Plant Quarantine. Res Bull Plant Prot Japan 27:87-92

McClay AS, Sobhian R, Zhang W (2001) Galium spurium L., false cleavers (Rubiaceae): 358-361. In: Mason PG, Huber JT (eds) Biological Control Programmes in Canada, 1981-2000. Oxon, UK

McNeely JA, Mooney HA, Neville LE, Johan Schei P, Waage JK (2001) Global strategy on invasive alien species. IUCN, Gland and Cambridge, p 50

Mead FA (1993) Entomology section. Tri-ology 32(4):3

Michels Jr GJ, Carney VA, Lydon J, Ochoa R, Renn RL (2009) New records for Aceria anthocoptes (Acari: Eriophyidae) occurring on Canada thistle in Colorado, Nebraska and Wyoming. Entomol News 483-491

Michigan State University (2004) Arthropods resistance pesticide database 2004-2009, Whalon ME, MotaSanchez D, Hollingworth RM, Duynslager E (eds). http://www.pesticideresistance.com/. Accessed 12 Mar 2009

Michalska K, Skoracka A, Navia D, Amrine Jr JW (2009) Behavioural studies on eriophyoid mites—an overview. Exp Appl Acarology. doi:10.1007/s10493-009-9319-2

Mito T, Uesugi T (2004) Invasive alien species in Japan: the status quo and the new regulation for prevention of their adverse effects. Global Environ Res 8(2):171-191 
Mohanasundaram M (1981) Record of rhyncaphytoptid gall mites (Rhyncaphytoptidae: Eriophyoidea) from South India. Oriental Insects 15:45-55

Molins RA (2001) Food irradiation: principles and applications. John wiley, Washington, p 472

Moore D (1986) Bract arrangement in the coconut fruit in relation to attack by the coconut mite Eriophyes guerreronis Keifer. Trop Agric 63:285-288

Moore D, Howard FW (1996) Coconuts. In: Lindquist EE, Sabelis MW, Bruin J (eds) Eriophyoid mites: their biology, natural enemies and control. Elsevier, The Netherlands, pp 561-570

Moraes GJ, Zacarias MS (2002) Use of predatory mites for the control of eriophyid mites. In: Fernando LCP, Moraes GJ de, Wickramananda IR (eds) Proceedings of the international workshop on coconut mite (Aceria guerreronis), Lunuwila. Coconut Research Institute, pp 78-88

Muthiah C, Bhaskaran R (2000) Major outbreak of eriophyid mite of coconut in India. The Planter $76: 243-246$

Nair CPR, Koshy PK (2000) Studies on coconut eriophyid mite, Aceria guerreronis Keifer in India. In Programme International Workshop on Coconut Mite (Aceria guerreronis), 1. Coconut Research Institute, Lunuwilla, $\mathrm{p} 7$

Nair CPR, Rajan P, Mohan Chandrika (2005) Coconut eriophyid mite Aceria guerreronis Keifer-an overview. Indian J Plant Prot 33:1-10

Navia D (2004) Ácaros Eriophyoidea (Prostigmata) associados a palmeiras (Arecaceae), com ênfase no ácaro do coqueiro, Aceria guerreronis Keifer-espectro de hospedeiros e aspectos biogeográficos. Thesis presented at University of São Paulo. http://www.teses.usp.br/teses/disponiveis/11/11146/ tde-02072004-142301/. Accessed 11 Apr 2009

Navia D, Flechtmann CHW (2008) Eriophyoid mites intercepted from plant germplasm in Braziladdressing questions on new introduction pathways. In: Sixth European Congress of Acarology. Abstracts, Montpellier. European Association of Acarologists (EURAAC), pp 58

Navia D, De Moraes GJ, Roderick G, Navajas M (2005) The invasive coconut mite Aceria guerreronis (Acari: Eriophyidae): Origin and invasion sources inferred from mitochondrial (16S) and nuclear (ITS) sequences. Bull Entomol Res 95(6):505-516

Navia D, Truol G, Mendonça RS, Sagadín M (2006) Aceria tosichella Keifer (Acari: Eriophyidae) from Wheat Streak Mosaic Virus-infected wheat plants in Argentina. Int J Acarol 32:189-193

Navia D, Moraes GJ de, Flechtmann CHW (2007a) Phytophagous mites as invasive alien species: quarantine procedures. In: Morales-Malacara JB, Behan-Pelletier V, Ueckermann E, Pérez TM, Estrada E, Gispert C, Badii M (eds) Acarology: Proceedings of the XI international congress. Merida, México, pp 307-316

Navia D, Mendonça RS, Batista MF, Truol G, Pereira PRVS, Guedes JVC, Castiglioni E, Morel NNE (2007b) The Wheat Curl Mite, Aceria tosichella Keifer, and associated viruses, Wheat streak mosaic virus and High plain virus - the risks posed to cereal crops in South America In: Proceedings XVI International Plant Protection Congress, Glasgow, 2: 612-613

Navajas M, Navia D (2009) DNA-based methods for eriophyoid mite studies: review, critical aspects, prospects and challenges. Exp Appl Acarology. doi:10.1007/s10493-009-9301-z

Nico L, Fuller P (1999) Spatial and temporal patterns of non-indigenous fish introductions in the United States. Fisheries 24:16-27

NRC (2002) Predicting invasions of non-indigenous plants and plant pests. National Academic Press, Washington

Ochoa R (2005) Invasive plant-feeding mite species (Acari: Prostigmata). http://www.sel.barc.usda.gov/ acari/content/invasivespecies.html. Accessed on April 2009

Ochoa R, Amrine Jr JW (2007) Aceria zeala (Keifer)—A mite new to North America has been found in a California greenhouse. (http://www.pestalert.org/viewArchPestAlert_print/). Accessed Apr 2009

Ochoa R, Erbe EF, Wergin WP, Frye C, Lydon G (2001) The presence of Aceria anthocoptes (Nalepa) (Acari: Eriophyidae) on Cirsium species in the United States. Int J Acarol 27(3):179-187

Oganezova GG, Pogosova AR (1994) Ecology and biology of Trisetacus kirghisorum (Acariformes, Tetrapodili). Zoologicheskii-Zhurnal 73:58-63

Oldfield GN (1996) Diversity and host plant specificity. In: Lindquist EE, Sabelis MW, Bruin J (eds) Eriophyoid mites: their biology, natural enemies and control. Elsevier, The Netherlands, pp 199-216

Oldfield GN, Proeseler G (1996) Eriophyoid mites as vectors of plant pathogens. In: Lindquist EE, Sabelis MW, Bruin J (eds) Eriophyoid mites: their biology, natural enemies and control. Elsevier, The Netherlands, pp 259-275

Ortega CA, Rodriguez VJ, Garibay CV (1967) Investigaciones preliminares sobre el eriófido del fruto del cocotero Aceria guerreronis Keifer, en la Costa Grande Guerrero (México). Oleaginéux 6:371-372

Ostoja-Starzewski JC, Matthews L (2006) Onion mite Aceria tulipae. Plant Pest Notice No. 41. CSL, New York 
Pearson DE, Callaway RM (2005) Indirect nontarget effects of host-specific biological control agents: implications for biological control. Biol Control 35:288-298

Pereira PRVS, Navia D, Salvadori JR, Lau D (2009) Occurrence of Aceria tosichella in Brazil. Pesq Agropec Bras 44(5):539-542

Perring TM (1996) Vegetables. In: Lindquist EE, Sabelis MW, Bruin J (eds) Eriophyoid mites: their biology, natural enemies and control. Elsevier, The Netherlands, pp 593-610

Pimentel D (2002) Introduction: non-native species in the world. In: Pimentel D (ed) Biological invasions: economic and environmental costs of alien plant, animal and microbe species. CRC Press, Boca Ratón, pp 3-8

Quilici S, Kreiter S, Ueckermann EA, Vancenot D (1997) Predatory mites (Acari) from various crops on Reunion Island. Int J Acarol 23(4):283-291

Raga A, Mineiro JLC, Sato ME, Moraes GJ, Flechtmann CHW (2008) Primeiro relato de Eriophyes litchi Keifer (Prostigmata: Eriophyidae) em plantas de lichia no Brasil. In: Anais do XXII Congresso Brasileiro de Entomologia, 2008, Uberlândia. Sociedade Entomológica do Brasil (CD)

Ramaraju K, Rabindra RJ (2002) Palmyra, Borassus flabellifer L. (Palmae): a host of the coconut eriophyid mite Aceria guerreronis Keifer. Pest Manag Hort Ecosyst 7:149-151

Ramaraju K, Natarajan K, Sundara Babu PC, Palanisamy S, Rabindra RJ (2002) Studies on coconut eriophyid mite, Aceria guerreronis Keifer in Tamil Nadu, Índia. In Fernando LCP, Moraes GJ de, Wickramananda IR (Eds) Proceedings of the international workshop on coconut mite (Aceria guerreronis), Lunuwila. Coconut Research Institute, pp 13-31

Randall JM, Marinelli J (1996) Invasive plants: weeds of the global garden. Science Press, New York

Robbs CF, Peracchi AL (1965) Sobre a ocorrência de um ácaro prejudicial ao coqueiro (Cocos nucifera L.). Anais da Reunião Fitossanitária, Rio de Janeiro, Ministério da Agricultura, SDSV, pp 65-70

Rosenthal SS (1996) Aceria, Epitrimerus and Aculus species and biological control of weeds. In: Lindquist EE, Sabelis MW, Bruin J (eds) Eriophyoid mites: their biology, natural enemies and control. Elsevier, The Netherlands, pp 729-739

Sanchez-Sanchez H, Henry M, Cardenas-Soriano E, Alvizo-Villasana HF (2001) Identification of Wheat streak mosaic virus and its vector Aceria tosichella in Mexico. Plant Dis 85:13-17

Sathiamma B, Radhakrishnan Nair CPR, Koshi PK (1998) Outbreak of a nut infesting eriophyid mite. Eriophyes guerreronis (K.) in coconut plantations in India. Indian Coconut J 29:1-3

Šefrová H, Laštůvka Z (2005) Catalogue of alien animal species in the Czech Republic. Acta univ agric et silvic Mendel. Brun, LIII, No. 4, pp 151-170

Seguni Z (2002) Incidence, distribution and economic importance of the coconut eriophyid mite, Aceria guerreronis Keifer in Tanzanian coconut based cropping systems. In Fernando LCP, Moraes GJ de, Wickramananda IR (eds) Proceedings of the international workshop on coconut mite (Aceria guerreronis), Lunuwila Coconut Research Institute, pp 54-57

Seifers DL, Harvey TL, Kofoid KD, Stegmeier WD (1996) Natural infection of pearl millet and sorghum by wheat streak mosaic virus in Kansas. Plant Dis 80:179-185

Seifers DL, Harvey TL, Martin TJ, Jensen SG (1998) A partial host range of the High Plain Virus of corn and wheat. Plant Dis 82:875-879

Simoni S, Cantini R, Castagnoli M, Battisti A (2004) Impact and management of the eriophyoid mite Trisetacus juniperinus on the evergreen cypress Cupressus sempervirens. Agr Forest Entomol 6:175-180

Skoracka A (2008) Reproductive barriers between populations of the cereal rust mite Abacarus hystrix confirm their host specialization. Evol Ecol 22:607-616

Smith L, de Lillo E, Stoeva A, Cristofaro M, Rector M (2008) Challenges to evaluation of eriophyoid mites for biological control of invasive plants. In: Bertrand M, Kreiter S, McCoy KD, Migeon A, Navajas M, Tixier MS, Vial L (eds) Integrative acarology. Proceedings of the 6th European Congress European Association of Acarologists, pp 312-316

Smith L, de Lillo E, Amrine JW Jr (2009) Effectiveness of eriophyid mites for biological control of weedy plants and challenges for future research. Exp Appl Acarol. doi:10.1007/s10493-009-9299-2

Stephan D, Moeller I, Skoracka A, Ehrig F, Maiss E (2008) Eriophyid mite transmission and host range of a Brome streak mosaic virus isolate derived from a full-length cDNA clone. Arch Virol 153:181-185

Streito J, Coroller M, Kreiter S, Flechtmann CHW (2004) Un nouvel acarien ravageur des fuchsiasdécouverte en France d'Aculops fuchsiae dont c'est le premier signalement en Europe. Phytoma. La Défense des Végétaux, n. 572: 32-34

Suarez A (1991) Distribución y evaluación de daños del acaro Eriophyes guerreronis en plantaciones de cocotero de la región de Baracoa. Protección de Plantas 1:75-81 
Truol G, Sagadin M (2008a) Presencia de High plain virus (HPV) nueva enfermedad del cultivo de trigo en La Província de Buenos Aires. In: VII Congreso Nacional de Trigo, Santa Rosa, Argentina. Resúmenes. INTA/UNIPALM, p 4

Truol G, Sagadin M (2008b) Virosis de los cereales detectadas en Argentina. In: Workshop en virosis de cereales transmitidas por el ácaro Aceria tosichella-Wheat streak mosaic virus y High plain virus-en los países del Cono Sur: situación, detección y manejo. Balcarce, Argentina. Libro de Resúmenes. INTA-IFFIVE, pp 21-22

Truol G, French R, Sagadin M, Arneodo J (2004) First report of wheat streak mosaic virus infecting wheat in Argentina. Austral Plant Path 33:137-138

Truol G, Sagadin M, Melchiorre G, Izaurralde J (2008) Enfermedades virales asociadas al cultivo de trigo en Argentina: Virus transmitidos por semilla y de importancia en el marco de las exportaciones. Detección en Argentina de sitios geográficos con presencia de Wheat streak mosaic virus (WSMV). Informe N. 6, INTA-IFFIVE, Córdoba, Argentina, ISBN 987-521-031-5. 2008, p 3

Verma BR, Kapur M (1990) Eriophyid mites (Acari: Eriophyoidea) of arid zone fruit crops and quarantine. Ind J Ent 52:249-252

Vitousek PM, D'Antonio CM, Loope LL, Rejmanek M, Westbrooks R (1997) Introduced species: a significant component of human-caused global change. New Zealand J Ecol 21:1-16

Welbourn WC (1995) Entomology section. Tri-ology 34(3): 4. http://www.doacs.state.fl.us/pi/enpp/triology/ archive/95-5\&6all.htm\#ent. Accessed April 2009

Welbourn WC (1996) Entomology section. Tri-ology 35(3): 3 http://www.doacs.state.fl.us/pi/enpp/triology/ archive/96-5\&6all.htm\#ent. Accessed April 2009

Welbourn WC (2000) Entomology section. Tri-ology 39(2): 5 http://www.doacs.state.fl.us/pi/enpp/triology/ archive/00-mar-apr.html\#ent. Accessed April 2009

Welbourn WC (2005) Entomology section. Tri-ology 44(1): 8 http://www.doacs.state.fl.us/pi/enpp/triology/ archive/4401.pdf. Accessed April 2009

Welbourn WC (2007a) Entomology section. Tri-ology 46(2): 5 http://www.doacs.state.fl.us/pi/enpp/ triology/archive/4602.pdf. Accessed April 2009

Welbourn WC (2007b) Entomology section. Tri-ology 46(4): 5 http://www.doacs.state.fl.us/pi/enpp/ triology/archive/4604.pdf. Accessed April 2009

Welbourn WC (2008a) Entomology section. Tri-ology 47(1): 4 http://www.doacs.state.fl.us/pi/enpp/ triology/archive/4701.pdf. Accessed April 2009

Welbourn WC (2008b) Entomology section. Tri-ology 47(1): 5 http://www.doacs.state.fl.us/pi/enpp/ triology/archive/4701.pdf. Accessed April 2009

Welbourn WC (2008c) Entomology section. Tri-ology 47(5): 7 http://www.doacs.state.fl.us/pi/enpp/ triology/archive/4705.pdf. Accessed April 2009

Welbourn C, Rodriques JC, Peña JE (2008) The hibiscus erineum mite, Aceria hibisci (Acari: Eriophyidae) a new introduction in the Caribbean and a potential threa to Florida's Hibiscus. University of Florida IFAS Publicatin ENY http://edis.ifas.ufl.edu/IN777. Accessed April 2009

Wheeler AG Jr, Hoebeke ER (2009) Adventive (Non-Native) insects: importance to science and society. In: Foottit R, Adler P (eds) Insect biodiversity: science and society. Blackwell Publishing, UK, pp 475-521

Willis AJ, Berenson PR, Ash JE (2003) Impacts of a weed biocontrol agent on recovery from water stress in a target and non-target Hypericum species. J Appl Ecol 40:320-333

Xie Yan, Zhenyu Li, Gregg WP, Dianmo Li (2000) Invasive species in China—an overview. Biodiv and Conserv 10:1317-1341

Zuluaga CI, Sánchez PA (1971) La roña o escoriación de los frutos del cocotero (Cocos nucifera L.) en Colombia. Acta Agronomica: 133-139 